\title{
Determination of differential gene expression profiles in superficial and deeper zones of mature rat articular cartilage using RNA sequencing of laser micro- dissected tissue specimens
}

\author{
Yoshifumi Mori ${ }^{1}$, Ung-il Chung ${ }^{2}$, Sakae TANAKA ${ }^{1}$, and Taku SAIto ${ }^{1,3}$ \\ ${ }^{1}$ Sensory \& Motor System Medicine, ${ }^{2}$ Center for Disease Biology and Integrative Medicine, Faculty of Medicine, ${ }^{3}$ Bone and Cartilage \\ Regenerative Medicine, University of Tokyo, 7-3-1 Hongo, Bunkyo-ku, Tokyo 113-8655, Japan
}

(Received 16 May 2014; and accepted 27 May 2014)

\begin{abstract}
Superficial zone (SFZ) cells, which are morphologically and functionally distinct from chondrocytes in deeper zones, play important roles in the maintenance of articular cartilage. Here, we established an easy and reliable method for performance of laser microdissection (LMD) on cryosections of mature rat articular cartilage using an adhesive membrane. We further examined gene expression profiles in the SFZ and the deeper zones of articular cartilage by performing RNA sequencing (RNA-seq). We validated sample collection methods, RNA amplification and the RNA-seq data using real-time RT-PCR. The combined data provide comprehensive information regarding genes specifically expressed in the SFZ or deeper zones, as well as a useful protocol for expression analysis of microsamples of hard tissues.
\end{abstract}

Osteoarthritis (OA), a chronic degenerative joint disorder characterized by articular cartilage destruction, is a major public health issue, causing pain and disability of the elderly worldwide $(5,8)$. Although effective disease-modifying treatments for OA have not been developed, its etiopathogenesis has been addressed in recent clinical studies. Cartilage degeneration is first observed at the articular surface in the form of fibrillation (24). Once the surface is disrupted, deeper cartilage layers are subsequently degraded (24).

Articular cartilage (AC) is composed of three layers: the superficial (SFZ), middle and deep zones. The SFZ, the outermost surface layer adjacent to the joint cavity, is histologically distinct from the deeper zones. In the SFZ, collagen fibers align parallel to the articular surface, in contrast to their vertical

Address correspondence to: Taku Saito, M.D., Ph.D., Associate Professor

Bone and Cartilage Regenerative Medicine, Faculty of Medicine, University of Tokyo, Hongo 7-3-1, Bunkyo-ku, Tokyo 113-8655, Japan

Tel: +81-3-3815-5411 (ext. 37369), Fax: +81-3-3818-4082

E-mail: tasaitou-tky@umin.ac.jp alignment in the deeper layers $(2,17)$. SFZ cells, which also display parallel alignment, are smaller than chondrocytes in the deeper layers and exhibit characteristic flat morphology (10). SFZ cells produce lubricin, encoded by Proteoglycan4 (Prg4), for surface lubrication. An homozygous mutant of the human PRG4 gene causes the autosomal recessive camptodactyly-arthropathy-coxa vara-pericarditis syndrome that shows congenital or early-onset camptodactyly and childhood-onset noninflammatory arthropathy $(1,16)$. Mice lacking $\operatorname{Prg} 4(\operatorname{Prg} 4-/-)$ exhibit early onset of osteoarthritis (25). In addition, chondrocytes obtained from SFZ display higher proliferative activity than those from deeper AC zones, implying that SFZ might be the main cell source of cartilage regeneration (32). Despite the potential roles of SFZ in the etiopathogenesis and pathophysiology of OA, apart from the involvement of Wnt/ $\beta$-catenin signaling, TGF- $\beta$ /BMP signaling and high mobility group box 2 (HMGB2), molecular mechanisms regulating the differentiation and maintenance of SFZ are still unknown $(12,22,28)$. This lack of data is mainly because comprehensive in vivo gene expression analysis of the SFZ is difficult due to its thinness, which makes it difficult to obtain SFZ-spe- 
cific samples.

To address this issue, we focused on a microsampling technique based on laser microdissection (LMD). LMD is an innovative technology that enables the isolation of a micro-area of tissue and has been widely used for a variety of biological research. Although LMD from a frozen sample is the ideal method for collection of RNA, preparation of a cryosection from hard tissue is difficult by conventional methods. In the present study, we aimed to establish an easy and reliable method for performance of LMD on cryosections of mature rat articular cartilage and for subsequent performance of RNA sequencing (RNA-seq) to obtain gene expression profiles for both the SFZ and deeper AC zones.

\section{MATERIALS AND METHODS}

Specimen preparation. All animal experiments were undertaken according to the guidelines of the Animal Care and Use Committee of the University of Tokyo. Ten-week-old male Sprague Dawley rats (Sankyo Laboratories, Tokyo, Japan) were sacrificed by cervical dislocation under anesthesia. A ringshaped skin incision was made at the height of the rib cage, the skin was dragged distally and the distal flap was inverted to expose the lower extremities. The left knee was then disarticulated, the medial and lateral menisci were detached and the tibia was cut at its shaft. The proximal tibia was immediately and directly placed into liquid nitrogen. Frozen sections were embedded in pre-cooled SCEM compound (Section-lab, Hiroshima, Japan) and stored at $-80^{\circ} \mathrm{C}$ until further analysis.

For H\&E staining, $10-\mu \mathrm{m}$ paraffin-embedded sections were prepared from 10-week-old Sprague Dawley rats as described previously (18). H\&E staining was performed according to a standard protocol.

Laser microdissection (LMD). We performed LMD using frozen sections prepared by Kawamoto's film method $(11,20)$. Specimens were placed into a Leica CM3050S (Leica Microsystems, Wetzlar, Germany) at $-30^{\circ} \mathrm{C}$ and cut coarsely in a frontal plane until a desired surface was exposed. The adhesive surface of Cryofilm Type IIC (Section-lab) was then attached to the specimen and $10-\mu \mathrm{m}$-thick sections were cut. The specimen with attached film was fixed to a metal frame using a double-sided tape (Nichiban, Tokyo, Japan). This metal frame was prepared from a membrane slide (PEN-membrane, $2.0 \mu \mathrm{m}$ ) whose PEN-membrane was removed prior to use. The fixed specimen and attached film were stored in the gas layer of liquid nitrogen until microdissection.

To prevent RNA degradation, frozen specimens (prior to thawing) were immediately soaked in $80 \%$ ethanol for $30 \mathrm{~s}$, then in $100 \%$ ethanol for $1 \mathrm{~min}$ (twice), then in xylene for $5 \mathrm{~min}$ at room temperature and subsequently they were dried for $5 \mathrm{~min}$. Specimens were then placed in a Leica LMD6500 (Leica Microsystems). Microdissection of the section was performed using the following settings: Power 50, Aperture 30 and Speed 5. Samples were collected in the cap of a $200 \mu \mathrm{L}$ tube pre-filled with $50 \mu \mathrm{L}$ of XB buffer of the Arcturus Picopure RNA isolation Kit (Thermo Fisher Scientific, Waltham, MA). SFZ and deeper AC samples from two slices were obtained for each rat. Samples were stored at $-80{ }^{\circ} \mathrm{C}$ until mRNA extraction.

RNA extraction and amplification. RNA extraction was performed using the Picopure RNA isolation Kit according to the manufacturer's protocol. RNA was collected in $11 \mu \mathrm{L}$ of EB buffer, $1.5 \mu \mathrm{L}$ of which were then used for checking RNA purity using NanoDrop (Thermo Fisher Scientific). We then amplified the remaining sample by two rounds of in-vitro transcription using the Arcturus RiboAmp HS PLUS kit (Thermo Fisher Scientific) according to the manufacturer's protocol. Amplified RNA (aRNA) was obtained in $30 \mu \mathrm{L}$ of RNA elution buffer, $1.5 \mu \mathrm{L}$ of which were again analyzed using NanoDrop to check quantity and purity.

Real-time RT-PCR. One microgram of aRNA was reverse-transcribed using the QuantiTect ReverseTranscription kit (Qiagen, Hilden, Germany) without performing the genomic DNA elimination reaction. The resultant $20 \mu \mathrm{L}$ of cDNA solution was diluted to $100 \mu \mathrm{L}$ with distilled water. For real-time RT-PCR analysis, the quantity of DNA polymerase was increased versus the standard protocol to rapidly amplify aRNAs with a small copy number (4). Reagents were prepared as follows: FastStart Universal SYBR Green Master (Roche Diagnostics, Basel, Switzerland) $10 \mu \mathrm{L}$; FastStart Taq DNA Polymerase (5 U/ $\mu \mathrm{L}$, Roche) $0.4 \mu \mathrm{L}$; forward Primer $(10 \mu \mathrm{M}) 2 \mu \mathrm{L}$; Reverse Primer $(10 \mu \mathrm{M}) 2 \mu \mathrm{L}$; distilled water $3.6 \mu \mathrm{L}$, aRNA solution $2 \mu \mathrm{L}$, and were run in triplicate on a Thermal Cycler Dice (Takara Bio, Otsu, Japan). Relative expression levels were calculated by the delta-delta CT method using Gapdh as an internal control. Primer pairs used are shown in Table 1.

RNA sequencing (RNA-seq). A cDNA library was constructed according to the TrueSeq RNA Sample 
Table 1 List of primers used for real-time RT-PCR

\begin{tabular}{lllc}
\hline \multicolumn{1}{c}{ Gene } & \multicolumn{1}{c}{ Forward primer } & \multicolumn{1}{c}{ Reverse primer } & $\begin{array}{c}\text { Product } \\
\text { size }(\mathrm{bp})\end{array}$ \\
\hline Gapdh & TGCACCACCAACTGCTTAGC & GGATGCAGGGATGATGTTCT & 177 \\
Col2al & ATGACTTTCCTCCGTCTACTGTCC & TGATGGTCTTGCCCCACTTAC & 226 \\
$P r g 4$ & AACCTGACTGGCAAAGAAGAATG & TGGGAGGAAGAGGAGGAATAAATAG & 232 \\
Bmp 7 & GCCCTTCCTTTCCGTTCTATTT & CATCCCTCACCGACCTCTTC & 129 \\
Tmem $176 a$ & CGTCAGGCAGGAAGAAGACC & GGTGGTGAAGGCAGAGGAGA & 117 \\
$W n t 9 a$ & TGGCAGTGGACACACAAGG & TCGCCACACAGTTGAGGTAGA & 80 \\
$F r z b$ & GGGAACTCATGGTGCCTTTT & GGAATGAGACTTTTAGGTGATTGG & 80 \\
Ibsp & CAAACATGAATACACGGTGTGAG & TTATCTGTAGGGGAGGGGTTGT & 93 \\
Grem 1 & GATTATGCAGGCTATGACGGAAC & GCCAAATTAGCTTCTATGAGACCA & 85 \\
\hline
\end{tabular}

Preparation V2 Guide Rev. C (Illumina, San Diego, $\mathrm{CA}$ ) and sequencing was performed using HiSeq 2000 (Illumina) according to the manufacturer's protocol. Then we normalized the sequence data by trimmed mean of $\mathrm{M}$ values method (26). The raw and processed data are available on GEO database with accession number GSE57377. After changing the measured value less than one to one, we calculated the fold change between SFZ and deeper AC.

Statistical analysis. Differences in mRNA expression levels between the SFZ and deeper AC as measured by real-time RT-PCR were analyzed using a paired $t$-test.

\section{RESULTS}

Histological evaluation of articular cartilage

In H\&E-stained paraffin sections of the proximal tibia, the SFZ was easily distinguishable from deeper AC layers by its flat-shaped nuclei and its alignment parallel to the joint surface (Fig. 1A, left). The SFZ was also easily distinguishable without any staining in frozen sections on adhesive membrane (Fig. 1A, right). We therefore performed LMD on unstained sections.

\section{$L M D, R N A$ purification and amplification}

Both SFZ and deeper AC layers were easily cut and collected using LMD. We obtained a pair of SFZ and deeper AC samples from each of seven rats. After purification using the Picopure RNA isolation kit and amplification using the RiboAmp HS Plus kit, we ultimately obtained 4.1 to $28.0 \mu \mathrm{g}$ aRNA from SFZ samples, and 4.0 to $74.6 \mu \mathrm{g}$ from deeper AC samples.
Validation of accurate sampling by real-time $R T$ PCR

After reverse-transcription of one $\mu \mathrm{g}$ aRNA, the accuracy of our sampling was validated by real-time RT-PCR. Previous studies showed that Prg4 is upregulated and Col2al is downregulated in the SFZ compared to deeper AC $(3,21,23,25)$. Our realtime RT-PCR results showed significant upregulation of Prg4 and downregulation of Col2al in SFZ as compared to deeper $\mathrm{AC}$, indicating that our differential sampling from these two distinct areas was appropriate (Fig. 1B).

\section{RNA-seq}

RNA-seq was performed on two pairs of SFZ and deeper AC samples. Fold change in expression of a gene between SFZ and deeper AC was averaged for two pairs (rat 1 and rat 2), and genes with more than a 2-fold change $(\log 2)$ on average were selected for further study. In total, 133 genes were found to be upregulated in SFZ and 758 genes were upregulated in deeper AC. The top 20 upregulated genes in SFZ and deeper AC are listed in Tables 2 and 3, respectively. Genes displaying lower fold changes are listed in Supplementary Tables S1 and $\mathrm{S} 2$, respectively. The present data showed upregulation of SFZ marker genes including Wnt $9 a$, Collal, Errfil, Clu, Thbs4, Igfbp5 and Prg4 in the SFZ (9, $15,21,25,27,32$ ), confirming that we appropriately collected RNA samples from SFZ and deeper AC.

Validation of $R N A$-seq results by real-time RT-PCR To confirm the reproducibility of the expression patterns obtained by RNA-seq, we analyzed the expression patterns of the three genes that displayed the highest fold change in the SFZ compared to deeper AC (Bmp7, Tmem176a, and Wnt9a) and those in deeper AC compared to the SFZ (Frzb, Ibsp and Grem 1) using real-time RT-PCR. The expression 

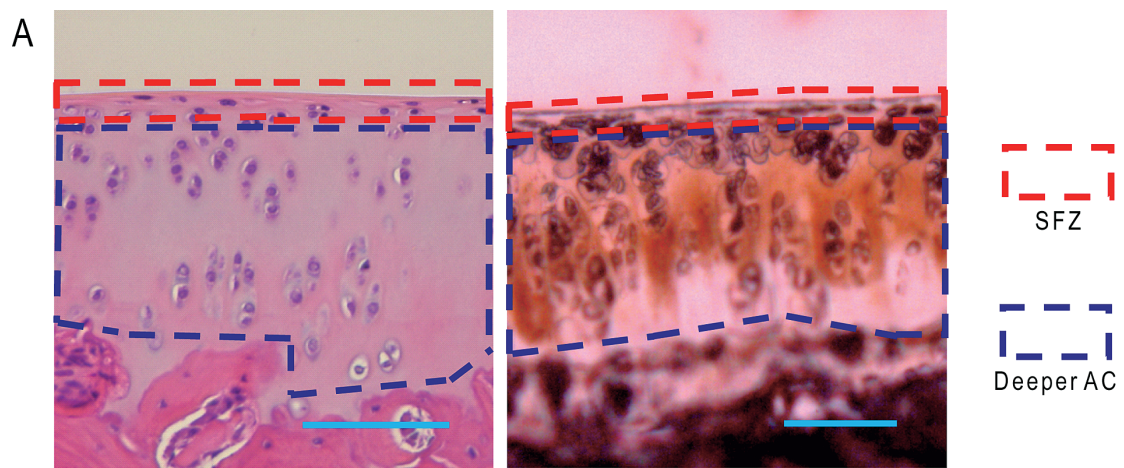

B
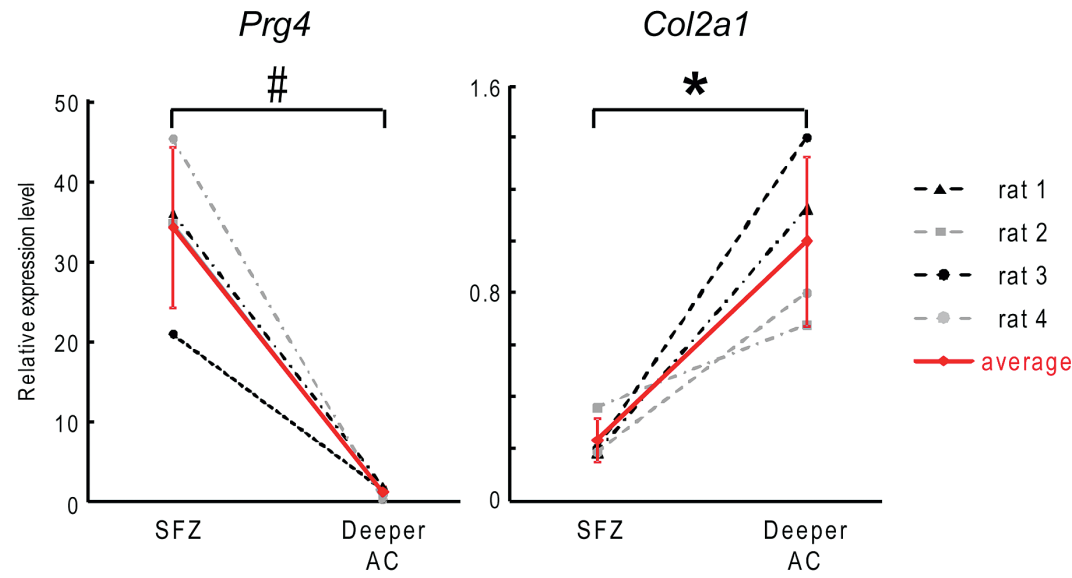

Fig. 1 Microscopic and real-time RT-PCR analysis of articular cartilage zones and chondrocytes. (A) H\&E staining of a paraffin-embedded section (left panel) and a frozen section on an adhesive membrane (right panel) of adult rat proximal tibia. Red and blue dashed line boxes indicate the superficial zone (SFZ) and deeper articular cartilage (AC), respectively. Scale bars, $100 \mu \mathrm{m}$. (B) mRNA levels of Prg4 and Col2a1 in chondrocytes in the SFZ and deeper AC from four rats (rat 1 to 4 ), determined using real-time RT-PCR. All data are shown as means \pm SD. ${ }^{*} P<0.05,{ }^{*} P<0.005$.

patterns of all six genes as determined by real-time RT-PCR were similar to those determined by RNAseq (Fig. 2). Significant differences were observed in the mRNA levels of all genes except for Bmp7 between the two zones, consistent with the results of the RNA-seq (Fig. 2).

\section{DISCUSSION}

In the present study, we analyzed gene expression profiles of chondrocytes in the SFZ and deeper zones of mature rat articular cartilage using RNAseq of laser microdissected tissue specimens. Since the articular cartilage is adjacent to the subchondral bone and the SFZ is extremely narrow, we had to optimize the conditions for all steps of protocol including preparation of a fine cryosection from hard tissue, specific dissection of SFZ, and reliable amplification of a small amount of RNA. Here, we established for the first time a successful procedure for examination of the RNA expression profile of a micro-region of hard tissue using a combination of cryosectioning employing an adhesive membrane, LMD and RNA-seq.

Recent studies indicate that SFZ cells play essential roles in the homeostasis of articular cartilage $(25,27,28,32)$. The previous studies analyzed the expression of genes in SFZ by performing microarray analysis of SFZ cells isolated from neonatal mouse knee joints by digestion with trypsin and collagenase. However, the enzymatic treatment procedure might change the gene expression profile of SFZ from that in vivo (32). Since LMD is now the most commonly used commercially available microsampling procedure, we decided to use LMD for specific collection of SFZ cells. Although LMD has been widely used for sampling RNA, its application to a hard tissue such as bone has been rarely reported because of the difficulty of preparing fine cryosections of such tissue. Some previous studies reported LMD sampling of soft immature cartilage of rodent embryos or infants $(31,33)$. However, in our pre- 
Table 2 List of top 20 genes with higher expression in the SFZ than in deeper AC

\begin{tabular}{llc}
\hline Gene Symbol & \multicolumn{1}{c}{ Description } & Fold Change (log2) \\
\hline Bmp7 & bone morphogenetic protein 7 & 51.5 \\
Tmem176a & transmembrane protein 176A & 45.3 \\
Wnt9a & wingless-type MMTV integration site family, member 9A & 32.7 \\
Gldc & glycine dehydrogenase (decarboxylating) & 26.5 \\
Mov10 & Moloney leukemia virus 10 & 24.5 \\
Prss 23 & protease, serine, 23 & 23.6 \\
Cidea & cell death-inducing DFFA-like effector a & 23.4 \\
Cdh13 & cadherin 13 & 23.3 \\
Colla1 & collagen, type I, alpha 1 & 22.7 \\
Kcnj8 & potassium inwardly-rectifying channel, subfamily J, member 8 & 20.7 \\
Slc8a1 & solute carrier family 8 (sodium/calcium exchanger), member 1 & 19.6 \\
Lrrc52 & leucine rich repeat containing 52 & 19.6 \\
Bend5 & BEN domain containing 5 & 18.8 \\
Sass6 & spindle assembly 6 homolog (C. elegans) & 18.4 \\
Kera & keratocan & 16.5 \\
Dact2 & dapper, antagonist of beta-catenin, homolog 2 (Xenopus laevis) & 16.5 \\
Cldn11 & claudin 11 & 16.3 \\
Pion & pigeon homolog (Drosophila) & 13.6 \\
Htra4 & HtrA serine peptidase 4 \\
Arsi & arylsulfatase family, member I & 13.3 \\
\hline
\end{tabular}

Table 3 List of top 20 genes with higher expression in deeper AC than in the SFZ

\begin{tabular}{llc}
\hline Gene Symbol & \multicolumn{1}{c}{ Description } & Fold Change $(\log 2)$ \\
\hline Frzb & frizzled-related protein & 55.8 \\
Ibsp & integrin-binding sialoprotein & 45.9 \\
Grem1 & gremlin 1 & 45.5 \\
Rarres 1 & retinoic acid receptor responder (tazarotene induced) 1 & 43.9 \\
Dmp1 & dentin matrix acidic phosphoprotein 1 & 40.9 \\
Tnni2 & troponin I type 2 (skeletal, fast) & 38.7 \\
Gfap & glial fibrillary acidic protein & 35.0 \\
Arhgap18 & Rho GTPase activating protein 18 & 33.7 \\
F5 & coagulation factor V (proaccelerin, labile factor) & 32.8 \\
Etnk2 & ethanolamine kinase 2 & 31.9 \\
Ogfrl1 & opioid growth factor receptor-like 1 & 31.4 \\
R3hdml & R3H domain (binds single-stranded nucleic acids) containing-like & 28.6 \\
Mns1 & meiosis-specific nuclear structural 1 & 27.4 \\
Evi2a & ecotropic viral integration site 2A & 26.3 \\
Phospho1 & phosphatase, orphan 1 & 26.0 \\
Steap4 & STEAP family member 4 & 25.8 \\
Sptlc3 & serine palmitoyltransferase, long chain base subunit 3 & 23.8 \\
A2m & alpha-2-macroglobulin & 23.6 \\
Irx4 & iroquois homeobox 4 & 23.6 \\
Ill 7 b & interleukin 17B & 23.2 \\
\hline
\end{tabular}

liminary experiment, we were unable to make fine cryosections using the conventional methods due to subchondral bone beneath the articular cartilage. To overcome the difficulty, we adapted an unique cryosection method that uses an adhesive membrane to support the fine structure of the original tissue during the slicing procedure $(11,20)$. In addition to us- ing the method, we also immediately dehydrated the sliced sections to facilitate the subsequent LMD. Using the modified cryosection method we efficiently obtained RNA from micro-areas of the fine cryosections.

Since only a small amount of RNA can be obtained using the LMD method, an amplification pro- 

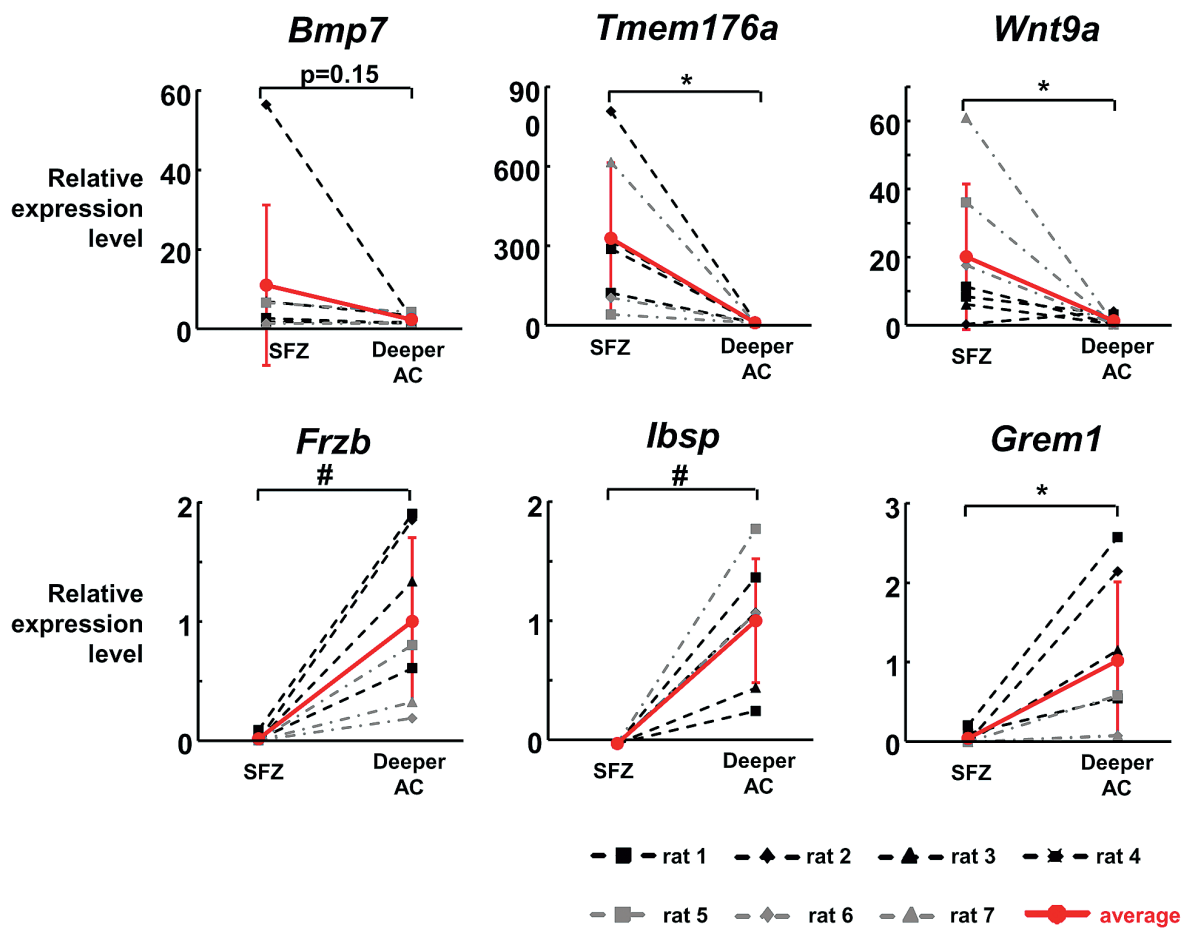

Fig. 2 mRNA levels of the three genes with the highest fold change in the SFZ compared to deeper AC (Bmp7, Tmem176a, and Wnt9a) and those in deeper AC compared to the SFZ (Frzb, Ibsp, and Grem1), in cartilage of SFZ and deeper AC from seven rats (rat 1 to 7 ) determined by real-time RT-PCR. All data are shown as means \pm SD. ${ }^{*} P<0.05,{ }^{\#} P<0.005$.

cedure is indispensable for further gene expression analysis. Of several commercial amplification kits that we tested, the RiboAmp HS Plus kit provided the most reproducible results in quantification of representative marker genes by real-time RT-PCR. However, because this amplification system utilizes an in vitro transcription method, it can only amplify mRNA but not microRNA. Combination of our method with other novel methods should make it possible to further analyze other types of RNA or DNA in the future.

Microarray technology has been a standard method for comprehensive gene expression analysis for many years. Numerous data have been accumulated in previous studies using microarray analyses. However, microarray analysis has several limitations, including background noise, that arise from hybridization of cDNA samples and probes and also has an upper limit of signal strength $(19,30)$. On the other hand, gene quantification using RNA-seq is based on the number of sequences read, therefore upper or lower limits of signal strength do not exist. In addition, RNA-seq is free from mishybridization, a major cause of false positive signals in microarray analysis $(19,30)$.

In addition to previously reported marker genes of the SFZ or deeper AC, the present data revealed distinct zone expression of several important molecules. Of the genes that were upregulated in the SFZ, Bmp 7 showed the highest fold change (Table 2), although significant difference was not observed in the mRNA levels of $B m p 7$ between the two zones due to the high variability in its expression level in the SFZ (Fig. 2). Bmp7 stimulates Prg4 expression in articular cartilage explants and cultured articular chondrocytes $(12,22)$. Based on these results, Bmp7 may function to stimulate production of ECM components in SFZ in a paracrine fashion. Of the genes that were upregulated in deeper AC, Wnt signaling antagonists including Frzb, Greml and Dkkl were highly upregulated with an average fold change value of $55.77,45.52$ and 4.01, respectively (Table 3, Supplementary Table S2). Leijten et al. reported that these three genes are upregulated in articular cartilage compared to growth plate cartilage based on microarray analysis of samples from adolescent human donors (14). In long-bone explant organ culture and in human mesenchymal stem cell culture, treatment with these proteins suppressed hypertrophic differentiation without affecting chondrogenesis (14), indicating that these genes may direct immature chondrocytes to mature articular chondrocytes, not 
to growth plate chondrocytes. Combined with our findings, the three genes may keep the character of articular chondrocytes in deeper zones from that of the SFZ cells or growth plate chondrocytes. Furthermore, Wnt/ $\beta$-catenin signaling is activated in the SFZ and stimulates SFZ-cell proliferation and Prg4 production $(13,32)$. All of these findings support the idea that distinct regulation of $\mathrm{Wnt} / \beta$-catenin signaling is essential for maintenance of the SFZ and deeper AC.

Fukui et al. previously performed microarray analysis of LMD samples obtained from the knee joint cartilage of OA patients $(6,7)$. They found that the gene expression patterns of chondrocytes differed according to the layer of articular cartilage in which they were situated, indicating that different phenotypes of articular chondrocytes in each layer may be essential for homeostasis of articular cartilage (6). In particular, the SFZ is indubitably the most potent layer for maintenance and repair of articular joints $(25,27,28)$. Furthermore, studies of the rodent OA model have demonstrated many molecules and signaling pathways that play a role in the pathophysiology of OA (29). The present data provide useful knowledge that will contribute to the development of zone-specific Cre mice and to further determination of novel molecules that regulate SFZ cells.

In conclusion, we established a reliable technique that employs cryosections with an adhesive membrane, LMD and RNA-seq for analysis of gene expression profiles of hard tissue. By using this method, we demonstrated different gene expression profiles in the SFZ and the deeper layers of rat articular cartilage. The present RNA-seq data resource will contribute to OA research aimed at further understanding the functions of SFZ.

\section{Acknowledgments}

We thank J. Sugita, R. Yamaguchi and H. Kawahara for technical assistance. This study was supported by a Grant-in-aid for Scientific Research from the Japanese Ministry of Education, Culture, Sports, Science and Technology (\#24390348).

\section{REFERENCES}

1. Bahabri SA, Suwairi WM, Laxer RM, Polinkovsky A, Dalaan AA and Warman ML (1998) The camptodactyly-arthropathycoxa vara-pericarditis syndrome: clinical features and genetic mapping to human chromosome 1. Arthritis Rheum 41, 730 735 .

2. Clark JM (1990) The organisation of collagen fibrils in the superficial zones of articular cartilage. J Anat 171, 117-130.

3. Craig FM, Bentley G and Archer CW (1987) The spatial and temporal pattern of collagens I and II and keratan sulphate in the developing chick metatarsophalangeal joint. Development 99, 383-391.

4. Erickson HS, Albert PS, Gillespie JW, Rodriguez-Canale J, Marston Linehan W, Pinto PA, Chuaqui RF and EmmertBuck MR (2009) Quantitative RT-PCR gene expression analysis of laser microdissected tissue samples. Nat Protoc 4, 902-922.

5. Felson DT and Zhang Y (1998) An update on the epidemiology of knee and hip osteoarthritis with a view to prevention. Arthritis Rheum 41, 1343-1355.

6. Fukui N, Ikeda Y, Ohnuki T, Tanaka N, Hikita A, Mitomi H, Mori T, Juji T, Katsuragawa Y, Yamamoto S, Sawabe M, Yamane S, Suzuki R, Sandell LJ and Ochi T (2008) Regional differences in chondrocyte metabolism in osteoarthritis: a detailed analysis by laser capture microdissection. Arthritis Rheum 58, 154-163.

7. Fukui N, Ikeda Y and Tanaka N (2011) The use of laser capture microdissection on adult human articular cartilage for gene expression analysis. Methods Mol Biol 755, 449-459.

8. Guccione AA, Felson DT, Anderson JJ, Anthony JM, Zhang Y, Wilson PW, Kelly-Hayes M, Wolf PA, Kreger BE and Kannel WB (1994) The effects of specific medical conditions on the functional limitations of elders in the Framingham Study. Am $J$ Public Health 84, 351-358.

9. Hartmann C and Tabin CJ (2001) Wnt-14 plays a pivotal role in inducing synovial joint formation in the developing appendicular skeleton. Cell 104, 341-351.

10. Hughes LC, Archer CW and ap Gwynn I (2005) The ultrastructure of mouse articular cartilage: collagen orientation and implications for tissue functionality. A polarised light and scanning electron microscope study and review. Eur Cell Mater 9, 68-84.

11. Kawamoto $T$ and Kawamoto K (2014) Preparation of thin frozen sections from nonfixed and undecalcified hard tissues using Kawamot's film method (2012). Methods Mol Biol 1130, 149-164.

12. Khalafi A, Schmid TM, Neu C and Reddi AH (2007) Increased accumulation of superficial zone protein (SZP) in articular cartilage in response to bone morphogenetic protein-7 and growth factors. J Orthop Res 25, 293-303.

13. Koyama E, Shibukawa Y, Nagayama M, Sugito H, Young B, Yuasa T, Okabe T, Ochiai T, Kamiya N, Rountree RB, Kingsley DM, Iwamoto M, Enomoto-Iwamoto M and Pacifici M (2008) A distinct cohort of progenitor cells participates in synovial joint and articular cartilage formation during mouse limb skeletogenesis. Dev Biol 316, 62-73.

14. Leijten JC, Emons J, Sticht C, van Gool S, Decker E, Uitterlinden A, Rappold G, Hofman A, Rivadeneira F, Scherjon S, Wit JM, van Meurs J, van Blitterswijk CA and Karperien M (2012) Gremlin 1, frizzled-related protein, and Dkk-1 are key regulators of human articular cartilage homeostasis. Arthritis Rheum 64, 3302-3312.

15. Malda J, ten Hoope W, Schuurman W, van Osch GJ, van Weeren PR and Dhert WJ (2010) Localization of the potential zonal marker clusterin in native cartilage and in tissueengineered constructs. Tissue Eng Part A 16, 897-904.

16. Marcelino J, Carpten JD, Suwairi WM, Gutierrez OM, Schwartz S, Robbins C, Sood R, Makalowska I, Baxevanis A, Johnstone B, Laxer RM, Zemel L, Kim CA, Herd JK, Ihle J, Williams C, Johnson M, Raman V, Alonso LG, Brunoni D, Gerstein A, Papadopoulos N, Bahabri SA, Trent JM and Warman ML (1999) CACP, encoding a secreted proteoglycan, is mutated in camptodactyly-arthropathy-coxa vara-peri- 
carditis syndrome. Nat Genet 23, 319-322.

17. Minns RJ and Steven FS (1977) The collagen fibril organization in human articular cartilage. J Anat 123, 437-457.

18. Mori Y, Saito T, Chang SH, Kobayashi H, Ladel CH, Guehring H, Chung UI and Kawaguchi H (2014) Identification of fibroblast growth factor-18 as a molecule to protect adult articular cartilage by gene expression profiling. $J$ Biol Chem 289, 10192-10200.

19. Nagalakshmi U, Wang Z, Waern K, Shou C, Raha D, Gerstein $M$ and Snyder M (2008) The transcriptional landscape of the yeast genome defined by RNA sequencing. Science 320, 1344-1349.

20. Nakamura Y, Nomura Y, Arai C, Noda K, Oikawa T, Kogure K, Kawamoto T and Hanada N (2007) Laser capture microdissection of rat periodontal ligament for gene analysis. Biotech Histochem 82, 295-300.

21. Nalin AM, Greenlee TK Jr. and Sandell LJ (1995) Collagen gene expression during development of avian synovial joints: transient expression of types II and XI collagen genes in the joint capsule. Dev Dyn 203, 352-362.

22. Niikura T and Reddi AH (2007) Differential regulation of lubricin/superficial zone protein by transforming growth factor beta/bone morphogenetic protein superfamily members in articular chondrocytes and synoviocytes. Arthritis Rheum 56, 2312-2321.

23. Pacifici M, Koyama E and Iwamoto M (2005) Mechanisms of synovial joint and articular cartilage formation: recent advances, but many lingering mysteries. Birth Defects Res $C$ Embryo Today 75, 237-248.

24. Poole AR, Guilak F and Abramson SB (2007) Etiopathogenesis of osteoarthritis. In: Osteoarthritis. (Moskowitz RW, Altman RD, Hochberg MC, Buckwalter JA and Goldberg VM, eds.) pp 27-49, Wolters Kluwer, Philadelphia.

25. Rhee DK, Marcelino J, Baker M, Gong Y, Smits P, Lefebvre V,
Jay GD, Stewart M, Wang H, Warman ML and Carpten JD (2005) The secreted glycoprotein lubricin protects cartilage surfaces and inhibits synovial cell overgrowth. $J$ Clin Invest 115, 622-631.

26. Robinson MD and Oshlack A (2010) A scaling normalization method for differential expression analysis of RNA-seq data. Genome Biol 11, R25.

27. Staal B, Williams BO, Beier F, Vande Woude GF and Zhang YW (2014) Cartilage-specific deletion of Mig-6 results in osteoarthritis-like disorder with excessive articular chondrocyte proliferation. Proc Natl Acad Sci USA 111, 2590-2595.

28. Taniguchi N, Carames B, Kawakami Y, Amendt BA, Komiya S and Lotz M (2009) Chromatin protein HMGB2 regulates articular cartilage surface maintenance via beta-catenin pathway. Proc Natl Acad Sci USA 106, 16817-16822.

29. Wang M, Shen J, Jin H, Im HJ, Sandy J and Chen D (2011) Recent progress in understanding molecular mechanisms of cartilage degeneration during osteoarthritis. Ann N Y Acad Sci 1240, 61-69.

30. Wang Z, Gerstein M and Snyder M (2009) RNA-Seq: a revolutionary tool for transcriptomics. Nat Rev Genet 10, 57-63.

31. Yamane S, Cheng E, You Z and Reddi AH (2007) Gene expression profiling of mouse articular and growth plate cartilage. Tissue Eng 13, 2163-2173.

32. Yasuhara R, Ohta Y, Yuasa T, Kondo N, Hoang T, Addya S, Fortina P, Pacifici M, Iwamoto $\mathrm{M}$ and Enomoto-Iwamoto $\mathrm{M}$ (2011) Roles of beta-catenin signaling in phenotypic expression and proliferation of articular cartilage superficial zone cells. Lab Invest 91, 1739-1752.

33. Zhang M, Pritchard MR, Middleton FA, Horton JA and Damron TA (2008) Microarray analysis of perichondral and reserve growth plate zones identifies differential gene expressions and signal pathways. Bone 43, 511-520. 
Gene expression in cartilage

Supplementary Table S1 List of genes with higher expression in the SFZ than in Deeper AC (ranks lower than 20th, fold change (log2) > 2)

\begin{tabular}{|c|c|c|}
\hline Gene Symbol & Description & Fold Change $(\log 2)$ \\
\hline Gp1bb & glycoprotein Ib (platelet), beta polypeptide & 12.7 \\
\hline Tt1112 & tubulin tyrosine ligase-like family, member 12 & 12.7 \\
\hline Aifm3 & apoptosis-inducing factor, mitochondrion-associated 3 & 12.3 \\
\hline Il15 & interleukin 15 & 10.7 \\
\hline $\mathrm{Cd} 74$ & Cd74 molecule, major histocompatibility complex, class II invariant chain & 10.6 \\
\hline Aldh1a2 & aldehyde dehydrogenase 1 family, member A2 & 10.6 \\
\hline Tcp11 & $\mathrm{t}$-complex protein 11 & 10.3 \\
\hline Myoc & myocilin & 10.0 \\
\hline Fbxo43 & F-box protein 43 & 9.3 \\
\hline MARCH8 & retinoblastoma-like $1(\mathrm{p} 107)$ & 9.1 \\
\hline Tead1 & TEA domain family member 1 & 8.3 \\
\hline Rph3al & rabphilin 3A-like (without $\mathrm{C} 2$ domains) & 8.2 \\
\hline Rxrg & retinoid $\mathrm{X}$ receptor gamma & 8.2 \\
\hline Errfil & ERBB receptor feedback inhibitor 1 & 8.0 \\
\hline Ntrk3 & neurotrophic tyrosine kinase, receptor, type 3 & 7.9 \\
\hline Slc2a9 & solute carrier family 2 (facilitated glucose transporter), member 9 & 7.6 \\
\hline Mfsd6 & major facilitator superfamily domain containing 6 & 7.6 \\
\hline Nudt6 & nudix (nucleoside diphosphate linked moiety X)-type motif 6 & 7.2 \\
\hline Tmprss2 & transmembrane protease, serine 2 & 7.0 \\
\hline Clu & clusterin & 6.5 \\
\hline Hs3st1 & heparan sulfate (glucosamine) 3-O-sulfotransferase 1 & 6.5 \\
\hline RGD1311164 & similar to DNA segment, Chr 6, Wayne State University 163, expressed & 6.2 \\
\hline Thbs4 & thrombospondin 4 & 6.2 \\
\hline Bmp4 & bone morphogenetic protein 4 & 6.1 \\
\hline Arhgdib & Rho, GDP dissociation inhibitor (GDI) beta & 5.5 \\
\hline Hbegf & heparin-binding EGF-like growth factor & 5.5 \\
\hline Casr & calcium-sensing receptor & 5.5 \\
\hline Mgll & monoglyceride lipase & 5.3 \\
\hline $\mathrm{Zc} 3 \mathrm{~h} 3$ & zinc finger $\mathrm{CCCH}$ type containing 3 & 5.2 \\
\hline Rnf208 & ring finger protein 208 & 5.2 \\
\hline Prrx 1 & paired related homeobox 1 & 5.2 \\
\hline Adhfe 1 & alcohol dehydrogenase, iron containing, 1 & 5.1 \\
\hline Egfl6 & EGF-like-domain, multiple 6 & 5.0 \\
\hline Igfbp5 & insulin-like growth factor binding protein 5 & 5.0 \\
\hline Sema $4 b$ & Semaphorin 4B & 4.9 \\
\hline RGD1309708 & similar to RIKEN cDNA $4930455 \mathrm{~F} 23$ & 4.9 \\
\hline Cxcl12 & chemokine (C-X-C motif) ligand 12 & 4.7 \\
\hline Slc6a12 & solute carrier family 6 (neurotransmitter transporter, betaine/GABA), member 12 & 4.6 \\
\hline $\mathrm{Cdh} 23$ & cadherin 23 (otocadherin) & 4.4 \\
\hline Ncald & neurocalcin delta & 4.4 \\
\hline
\end{tabular}




\begin{tabular}{|c|c|c|}
\hline Gene Symbol & Description & Fold Change $(\log 2)$ \\
\hline Itih3 & inter-alpha trypsin inhibitor, heavy chain 3 & 4.4 \\
\hline Gch1 & GTP cyclohydrolase 1 & 4.3 \\
\hline Pnpla2 & patatin-like phospholipase domain containing 2 & 4.3 \\
\hline Scara3 & scavenger receptor class $\mathrm{A}$, member 3 & 4.1 \\
\hline Sectm $1 b$ & secreted and transmembrane $1 \mathrm{~B}$ & 4.1 \\
\hline Ifi2 $2712 b$ & interferon, alpha-inducible protein 27 like 2B & 4.1 \\
\hline T111 & tolloid-like 1 & 3.9 \\
\hline Bik & BCL2-interacting killer (apoptosis-inducing) & 3.9 \\
\hline $\mathrm{Tc} 2 \mathrm{n}$ & tandem $\mathrm{C} 2$ domains, nuclear & 3.9 \\
\hline Nkx6-1 & NK6 homeobox 1 & 3.9 \\
\hline $\operatorname{Scg} 5$ & secretogranin $\mathrm{V}$ & 3.9 \\
\hline Lhfpl2 & lipoma HMGIC fusion partner-like 2 & 3.9 \\
\hline Cdon & Cdon homolog (mouse) & 3.8 \\
\hline Fhde1 & FH2 domain containing 1 & 3.7 \\
\hline Sult2b1 & sulfotransferase family, cytosolic, $2 \mathrm{~B}$, member 1 & 3.6 \\
\hline Msx 1 & msh homeobox 1 & 3.6 \\
\hline Ampd3 & adenosine monophosphate deaminase 3 & 3.6 \\
\hline Wnt11 & wingless-type MMTV integration site family, member 11 & 3.5 \\
\hline Rarres2 & retinoic acid receptor responder (tazarotene induced) 2 & 3.5 \\
\hline Clic2 & chloride intracellular channel 2 & 3.5 \\
\hline $\operatorname{Mfsd} 2 \mathrm{a}$ & major facilitator superfamily domain containing $2 \mathrm{~A}$ & 3.5 \\
\hline Gda & guanine deaminase & 3.5 \\
\hline Plekhb1 & pleckstrin homology domain containing, family B (evectins) member 1 & 3.3 \\
\hline Mgp & matrix Gla protein & 3.2 \\
\hline Egln 3 & EGL nine homolog 3 (C. elegans) & 3.2 \\
\hline Ppap2b & phosphatidic acid phosphatase type $2 \mathrm{~B}$ & 3.2 \\
\hline $\mathrm{Xrcc} 2$ & $\mathrm{X}$-ray repair complementing defective repair in Chinese hamster cells 2 & 3.1 \\
\hline Pigl & phosphatidylinositol glycan anchor biosynthesis, class L & 3.1 \\
\hline Nrk & Nik related kinase & 3.1 \\
\hline Hmen1 & hemicentin 1 & 3.1 \\
\hline MGC105649 & hypothetical LOC302884 & 3.1 \\
\hline Slc40a1 & solute carrier family 39 (iron-regulated transporter), member 1 & 3.0 \\
\hline Tspan13 & tetraspanin 13 & 3.0 \\
\hline Optc & opticin & 3.0 \\
\hline $\operatorname{Sec} 31 b$ & SEC31 homolog B (S. cerevisiae) & 3.0 \\
\hline Wdfy2 & WD repeat and FYVE domain containing 2 & 3.0 \\
\hline Rin2 & Ras and Rab interactor 2 & 2.9 \\
\hline Dagla & diacylglycerol lipase, alpha & 2.9 \\
\hline Jup & junction plakoglobin & 2.8 \\
\hline Rem1 & RAS (RAD and GEM)-like GTP-binding 1 & 2.8 \\
\hline Cstf3 & cleavage stimulation factor, $3^{\prime}$ pre-RNA, subunit 3 & 2.8 \\
\hline Clock & clock homolog (mouse) & 2.7 \\
\hline Mylk & myosin light chain kinase & 2.7 \\
\hline Crip1 & cysteine-rich protein 1 (intestinal) & 2.7 \\
\hline Plxdc2 & plexin domain containing 2 & 2.7 \\
\hline Zmym1 & zinc finger, MYM-type 1 & 2.7 \\
\hline Ptgs 1 & prostaglandin-endoperoxide synthase 1 & 2.7 \\
\hline Erbb3 & v-erb-b2 erythroblastic leukemia viral oncogene homolog 3 (avian) & 2.7 \\
\hline Pla1a & phospholipase A1 member A & 2.6 \\
\hline Ptpn21 & protein tyrosine phosphatase, non-receptor type 21 & 2.6 \\
\hline
\end{tabular}


Gene expression in cartilage

Supplementary Table S1 (continued)

\begin{tabular}{|c|c|c|}
\hline Gene Symbol & Description & Fold Change $(\log 2)$ \\
\hline Hipk4 & homeodomain interacting protein kinase 4 & 2.6 \\
\hline Ltbp2 & latent transforming growth factor beta binding protein 2 & 2.6 \\
\hline Ltbp4 & latent transforming growth factor beta binding protein 4 & 2.6 \\
\hline Sulf1 & sulfatase 1 & 2.6 \\
\hline $\operatorname{Prg} 4$ & proteoglycan 4 & 2.6 \\
\hline Ano6 & anoctamin 6 & 2.6 \\
\hline Fam163a & family with sequence similarity 163 , member A & 2.5 \\
\hline Cpne9 & copine family member IX & 2.5 \\
\hline Zfp70912 & zinc finger protein 709 -like 2 & 2.5 \\
\hline Arhgef19 & Rho guanine nucleotide exchange factor (GEF) 19 & 2.5 \\
\hline Sema3b & Semaphorin 3B & 2.5 \\
\hline Tnfrsf9 & tumor necrosis factor receptor superfamily, member 9 & 2.5 \\
\hline Gem & GTP binding protein (gene overexpressed in skeletal muscle) & 2.5 \\
\hline Zfp775 & zinc finger protein 775 & 2.5 \\
\hline Zbtb45 & zinc finger and BTB domain containing 45 & 2.4 \\
\hline Rcan1 & regulator of calcineurin 1 & 2.4 \\
\hline Got1 & glutamic-oxaloacetic transaminase 1 , soluble (aspartate aminotransferase 1) & 2.3 \\
\hline Def6 & differentially expressed in FDCP 6 homolog (mouse) & 2.3 \\
\hline Vps13a & vacuolar protein sorting 13 homolog A (S. cerevisiae) & 2.2 \\
\hline Des & desmin & 2.2 \\
\hline Osbp2 & oxysterol binding protein 2 & 2.2 \\
\hline Vstm4 & V-set and transmembrane domain containing 4 & 2.2 \\
\hline Crtc2 & CREB regulated transcription coactivator 2 & 2.2 \\
\hline
\end{tabular}


Supplementary Table S2 List of genes with higher expression in Deeper AC than in the SFZ (ranks lower than 20th, fold change (log2) > 2)

\begin{tabular}{|c|c|c|}
\hline Gene Symbol & Description & Fold Change $(\log 2)$ \\
\hline Olr397 & olfactory receptor 397 & 22.8 \\
\hline Alpl & alkaline phosphatase, liver/bone/kidney & 22.5 \\
\hline Batf & basic leucine zipper transcription factor, ATF-like & 22.4 \\
\hline Cks2 & CDC28 protein kinase regulatory subunit 2 & 22.4 \\
\hline Tas 2 r120 & taste receptor, type 2 , member 120 & 22.1 \\
\hline Timp4 & tissue inhibitor of metalloproteinase 4 & 22.0 \\
\hline Lysmd3 & LysM, putative peptidoglycan-binding, domain containing 3 & 21.3 \\
\hline Mmp23 & matrix metallopeptidase 23 & 20.1 \\
\hline Gmip & Gem-interacting protein & 19.8 \\
\hline Klhl38 & kelch-like 38 (Drosophila) & 19.5 \\
\hline Foxa2 & forkhead box A2 & 19.4 \\
\hline Fam111a & family with sequence similarity 111 , member A & 19.3 \\
\hline Zfp507 & zinc finger protein 507 & 19.2 \\
\hline Tecta & tectorin alpha & 19.2 \\
\hline Adam411 & a disintegrin and metallopeptidase domain 4-like 1 & 19.0 \\
\hline Kcna1 & potassium voltage-gated channel, shaker-related subfamily, member 1 & 18.6 \\
\hline Tsga13 & testis specific, 13 & 18.5 \\
\hline Ivns labp & influenza virus NS1A binding protein & 18.2 \\
\hline Amhr2 & anti-Mullerian hormone receptor, type II & 17.7 \\
\hline Nsdhl & $\mathrm{NAD}(\mathrm{P})$ dependent steroid dehydrogenase-like & 17.7 \\
\hline Mmp13 & matrix metallopeptidase 13 & 17.4 \\
\hline Sox13 & SRY (sex determining region Y)-box 13 & 17.3 \\
\hline Kcnk1 & potassium channel, subfamily $\mathrm{K}$, member 1 & 17.1 \\
\hline Slc6a1 & solute carrier family 6 (neurotransmitter transporter, GABA), member 1 & 17.1 \\
\hline Ssx2ip & synovial sarcoma, $\mathrm{X}$ breakpoint 2 interacting protein & 17.1 \\
\hline Dnm3 & dynamin 3 & 17.1 \\
\hline SEPT1 & NudC domain containing 1 & 16.9 \\
\hline Hsd17b13 & hydroxysteroid (17-beta) dehydrogenase 13 & 16.9 \\
\hline Akr1c19 & aldo-keto reductase family 1 , member $\mathrm{C} 19$ & 16.9 \\
\hline Tpbg & trophoblast glycoprotein & 16.6 \\
\hline Syt8 & synaptotagmin VIII & 16.5 \\
\hline Sphk1 & sphingosine kinase 1 & 16.4 \\
\hline Odz3 & odz, odd Oz/ten-m homolog 3 (Drosophila) & 16.2 \\
\hline Kcnk6 & potassium channel, subfamily K, member 6 & 15.9 \\
\hline Csrp2 & cysteine and glycine-rich protein 2 & 15.9 \\
\hline Hoxa13 & homeo box A13 & 15.6 \\
\hline Echdc2 & enoyl CoA hydratase domain containing 2 & 15.5 \\
\hline Pcdha5 & protocadherin alpha 5 & 15.3 \\
\hline SEPT11 & hyaluronan and proteoglycan link protein 4 & 15.0 \\
\hline Rhbdl2 & rhomboid, veinlet-like 2 (Drosophila) & 15.0 \\
\hline
\end{tabular}


Gene expression in cartilage

Supplementary Table S2 (continued)

\begin{tabular}{|c|c|c|}
\hline Gene Symbol & Description & Fold Change $(\log 2)$ \\
\hline Chd1 & chromodomain helicase DNA binding protein 1 & 15.0 \\
\hline Tfr2 & transferrin receptor 2 & 14.8 \\
\hline Abhd3 & abhydrolase domain containing 3 & 14.7 \\
\hline LOC100125362 & hypothetical protein LOC100125362 & 14.6 \\
\hline Vcpip1 & valosin containing protein $(\mathrm{p} 97) / \mathrm{p} 47$ complex interacting protein 1 & 14.6 \\
\hline RGD1306941 & similar to CG31122-PA & 14.4 \\
\hline Art3 & ADP-ribosyltransferase 3 & 14.3 \\
\hline Slc19a2 & solute carrier family 19 (thiamine transporter), member 2 & 14.3 \\
\hline Mcc & mutated in colorectal cancers & 14.1 \\
\hline Hadh & hydroxyacyl-CoA dehydrogenase & 14.1 \\
\hline Mybph & myosin binding protein $\mathrm{H}$ & 14.1 \\
\hline Tmem132e & transmembrane protein $132 \mathrm{E}$ & 14.1 \\
\hline Wwtr1 & WW domain containing transcription regulator 1 & 13.9 \\
\hline Cdv3 & carnitine deficiency-associated gene expressed in ventricle 3 homolog (mouse) & 13.8 \\
\hline Dact3 & dapper, antagonist of beta-catenin, homolog 3 (Xenopus laevis) & 13.7 \\
\hline Slc10a7 & solute carrier family 10 , member 7 & 13.6 \\
\hline Eln & elastin & 13.6 \\
\hline Fkbpl & FK506 binding protein-like & 13.5 \\
\hline LOC688390 & hypothetical protein LOC688390 & 13.4 \\
\hline Gstt1 & glutathione S-transferase theta 1 & 13.4 \\
\hline Myom1 & myomesin 1 & 13.4 \\
\hline Wdr53 & WD repeat domain 53 & 13.3 \\
\hline Prelid2 & PRELI domain containing 2 & 13.2 \\
\hline Ppp1r14c & protein phosphatase 1 , regulatory (inhibitor) subunit $14 \mathrm{c}$ & 13.1 \\
\hline Fam70b & family with sequence similarity 70 , member B & 13.1 \\
\hline Plk5 & polo-like kinase 5 & 13.0 \\
\hline Pcdh18 & protocadherin 18 & 12.9 \\
\hline Wasf2 & WAS protein family, member 2 & 12.9 \\
\hline Tfpi & tissue factor pathway inhibitor & 12.8 \\
\hline Irf5 & interferon regulatory factor 5 & 12.8 \\
\hline Kcnk2 & potassium channel, subfamily $\mathrm{K}$, member 2 & 12.7 \\
\hline Fmo4 & flavin containing monooxygenase 4 & 12.5 \\
\hline Olr1014 & olfactory receptor 1014 & 12.4 \\
\hline Ndrg4 & $\mathrm{N}$-myc downstream regulated gene 4 & 12.4 \\
\hline Arhgdig & Rho GDP dissociation inhibitor (GDI) gamma & 12.1 \\
\hline Pnkp & polynucleotide kinase 3 '-phosphatase & 12.1 \\
\hline Fgfr3 & fibroblast growth factor receptor 3 & 12.0 \\
\hline Masp1 & mannan-binding lectin serine peptidase 1 & 12.0 \\
\hline Mtpn & myotrophin & 12.0 \\
\hline Anpep & alanyl (membrane) aminopeptidase & 12.0 \\
\hline Parva & parvin, alpha & 11.9 \\
\hline Fbp1 & fructose-1,6-bisphosphatase 1 & 11.9 \\
\hline LOC688459 & hypothetical protein LOC688459 & 11.9 \\
\hline Zfp689 & zinc finger protein 689 & 11.8 \\
\hline Rnase 10 & ribonuclease, RNase A family, 10 (non-active) & 11.7 \\
\hline Pdpr & pyruvate dehydrogenase phosphatase regulatory subunit & 11.7 \\
\hline Igflr1 & IGF-like family receptor 1 & 11.7 \\
\hline Ina & internexin neuronal intermediate filament protein, alpha & 11.7 \\
\hline Ccrn41 & CCR4 carbon catabolite repression 4-like (S. cerevisiae) & 11.4 \\
\hline Serinc2 & serine incorporator 2 & 11.4 \\
\hline
\end{tabular}


Supplementary Table S2 (continued)

\begin{tabular}{|c|c|c|}
\hline Gene Symbol & Description & Fold Change $(\log 2)$ \\
\hline Nat1 & $\mathrm{N}$-acetyltransferase 1 & 11.4 \\
\hline SEPT5 & PYD and CARD domain containing & 11.3 \\
\hline Gpr22 & G protein-coupled receptor 22 & 11.2 \\
\hline Snrnp70 & small nuclear ribonucleoprotein 70 (U1) & 11.2 \\
\hline Tbccd1 & TBCC domain containing 1 & 11.2 \\
\hline Dnah1 & dynein, axonemal, heavy chain 1 & 11.2 \\
\hline RGD1565983 & similar to apurinic/apyrimidinic endonuclease 2 & 11.1 \\
\hline Kctd4 & potassium channel tetramerisation domain containing 4 & 11.1 \\
\hline Gpr171 & G protein-coupled receptor 171 & 11.0 \\
\hline Zfp444 & zinc finger protein 444 & 10.9 \\
\hline Pik3cb & phosphoinositide-3-kinase, catalytic, beta polypeptide & 10.9 \\
\hline Hlx & H2.0-like homeobox & 10.9 \\
\hline $\mathrm{Nrsn} 2$ & neurensin 2 & 10.9 \\
\hline Pgm3 & phosphoglucomutase 3 & 10.8 \\
\hline Lemt2 & leucine carboxyl methyltransferase 2 & 10.8 \\
\hline Trim43a & tripartite motif-containing $43 \mathrm{~A}$ & 10.8 \\
\hline Klf11 & Kruppel-like factor 11 & 10.8 \\
\hline Eid3 & EP300 interacting inhibitor of differentiation 3 & 10.8 \\
\hline RGD1562673 & similar to Prostatic spermine-binding protein precursor (SBP) & 10.8 \\
\hline $\mathrm{Cd} 248$ & CD248 molecule, endosialin & 10.7 \\
\hline Capn3 & calpain 3 & 10.7 \\
\hline MARCH1 & kelch-like 25 (Drosophila) & 10.7 \\
\hline SEPT7 & calreticulin 3 & 10.6 \\
\hline S1pr5 & sphingosine-1-phosphate receptor 5 & 10.6 \\
\hline Rrad & Ras-related associated with diabetes & 10.6 \\
\hline Vill & villin-like & 10.6 \\
\hline Fads1 & fatty acid desaturase 1 & 10.6 \\
\hline Irf6 & interferon regulatory factor 6 & 10.5 \\
\hline Dync1li1 & dynein cytoplasmic 1 light intermediate chain 1 & 10.4 \\
\hline Skap2 & src kinase associated phosphoprotein 2 & 10.4 \\
\hline Cd2ap & CD2-associated protein & 10.4 \\
\hline Clip2 & CAP-GLY domain containing linker protein 2 & 10.4 \\
\hline Pglyrp1 & peptidoglycan recognition protein 1 & 10.3 \\
\hline Bcas 1 & breast carcinoma amplified sequence 1 & 10.2 \\
\hline Fam117a & family with sequence similarity 117 , member $\mathrm{A}$ & 10.2 \\
\hline Cntf & ciliary neurotrophic factor & 10.2 \\
\hline Paox & polyamine oxidase (exo-N4-amino) & 10.2 \\
\hline Nagpa & $\mathrm{N}$-acetylglucosamine-1-phosphodiester alpha-N-acetylglucosaminidase & 10.2 \\
\hline $\mathrm{C} 2$ & complement component 2 & 10.2 \\
\hline RGD1312026 & similar to RIKEN cDNA C230081A13 & 10.1 \\
\hline Tuft1 & tuftelin 1 & 10.1 \\
\hline Acbd5 & acyl-CoA binding domain containing 5 & 10.1 \\
\hline Arhgap24 & Rho GTPase activating protein 24 & 10.0 \\
\hline Myole & myosin IE & 9.9 \\
\hline Slc22a18 & solute carrier family 22, member 18 & 9.9 \\
\hline Gpr68 & G protein-coupled receptor 68 & 9.8 \\
\hline Abhd10 & abhydrolase domain containing 10 & 9.7 \\
\hline Il17re & interleukin 17 receptor $\mathrm{E}$ & 9.7 \\
\hline Tfdp2 & transcription factor Dp-2 (E2F dimerization partner 2) & 9.7 \\
\hline Zfp800 & zinc finger protein 800 & 9.7 \\
\hline
\end{tabular}


Gene expression in cartilage

Supplementary Table S2 (continued)

\begin{tabular}{|c|c|c|}
\hline Gene Symbol & Description & Fold Change $(\log 2)$ \\
\hline Fgfr1 & Fibroblast growth factor receptor 1 & 9.6 \\
\hline Slc29a2 & solute carrier family 29 (nucleoside transporters), member 2 & 9.6 \\
\hline MARCH4 & DnaJ (Hsp40) homolog, subfamily C, member 5 gamma & 9.6 \\
\hline Pcdha13 & protocadherin alpha 13 & 9.5 \\
\hline Taok1 & TAO kinase 1 & 9.5 \\
\hline Prmt7 & protein arginine methyltransferase 7 & 9.5 \\
\hline Cpeb4 & cytoplasmic polyadenylation element binding protein 4 & 9.5 \\
\hline Poflb & premature ovarian failure $1 \mathrm{~B}$ & 9.4 \\
\hline MARCH7 & major facilitator superfamily domain containing 9 & 9.4 \\
\hline Crlf1 & cytokine receptor-like factor 1 & 9.3 \\
\hline Pole2 & polymerase (DNA directed), epsilon 2 (p59 subunit) & 9.3 \\
\hline Ankrd23 & ankyrin repeat domain 23 & 9.3 \\
\hline RGD1359634 & similar to RIKEN cDNA 1700088E04 & 9.2 \\
\hline Mms221 & MMS22-like, DNA repair protein & 9.1 \\
\hline Ppm11 & protein phosphatase, $\mathrm{Mg} 2+/ \mathrm{Mn} 2+$ dependent, $1 \mathrm{~L}$ & 9.1 \\
\hline Sh3bp2 & SH3-domain binding protein 2 & 9.1 \\
\hline SEPT3 & ferredoxin-fold anticodon binding domain containing 1 & 9.0 \\
\hline Spata2L & spermatogenesis associated 2-like & 9.0 \\
\hline Mal & mal, T-cell differentiation protein & 8.9 \\
\hline Matn3 & matrilin 3 & 8.9 \\
\hline Zfp583 & zinc finger protein 583 & 8.9 \\
\hline Letm2 & leucine zipper-EF-hand containing transmembrane protein 2 & 8.9 \\
\hline Cdk1 & cyclin-dependent kinase 1 & 8.8 \\
\hline Aspg & asparaginase homolog (S. cerevisiae) & 8.8 \\
\hline Zhx3 & zinc fingers and homeoboxes 3 & 8.8 \\
\hline Iqgap3 & IQ motif containing GTPase activating protein 3 & 8.8 \\
\hline Gpr116 & G protein-coupled receptor 116 & 8.7 \\
\hline Lrp4 & low density lipoprotein receptor-related protein 4 & 8.7 \\
\hline Mug1 & murinoglobulin 1 & 8.7 \\
\hline Mum111 & melanoma associated antigen (mutated) 1-like 1 & 8.7 \\
\hline Zap70 & zeta-chain (TCR) associated protein kinase & 8.7 \\
\hline Tmie & transmembrane inner ear & 8.7 \\
\hline Sorcs2 & sortilin-related VPS10 domain containing receptor 2 & 8.7 \\
\hline Scgb1c1 & secretoglobin, family $1 \mathrm{C}$, member 1 & 8.6 \\
\hline Pdlim3 & PDZ and LIM domain 3 & 8.6 \\
\hline Zfp112 & zinc finger protein 112 & 8.5 \\
\hline Slc13a5 & solute carrier family 13 , member 5 & 8.5 \\
\hline Slk & STE20-like kinase (yeast) & 8.5 \\
\hline Olr584 & olfactory receptor 584 & 8.4 \\
\hline Shbg & sex hormone binding globulin & 8.4 \\
\hline Slc12a1 & solute carrier family 12 , member 1 & 8.4 \\
\hline Mettl4 & methyltransferase like 4 & 8.4 \\
\hline Fam13a & family with sequence similarity 13 , member A & 8.3 \\
\hline Fem1b & fem-1 homolog b (C. elegans) & 8.3 \\
\hline Prkg2 & protein kinase, cGMP-dependent, type II & 8.3 \\
\hline Shq1 & SHQ1 homolog (S. cerevisiae) & 8.2 \\
\hline $\mathrm{Cdc} 7$ & cell division cycle 7 homolog (S. cerevisiae) & 8.2 \\
\hline Slc16a10 & solute carrier family 16 , member 10 & 8.2 \\
\hline Mecom & MDS1 and EVI1 complex locus & 8.1 \\
\hline Bdh1 & 3-hydroxybutyrate dehydrogenase, type 1 & 8.1 \\
\hline
\end{tabular}




\begin{tabular}{|c|c|c|}
\hline Gene Symbol & Description & Fold Change $(\log 2)$ \\
\hline Gap43 & growth associated protein 43 & 8.1 \\
\hline Cpamd8 & C3 and PZP-like, alpha-2-macroglobulin domain containing 8 & 8.1 \\
\hline Rnf11 & ring finger protein 11 & 8.0 \\
\hline Kif12 & kinesin family member 12 & 8.0 \\
\hline Slc4a8 & solute carrier family 4 , sodium bicarbonate cotransporter, member 8 & 8.0 \\
\hline Rhobtb2 & Rho-related BTB domain containing 2 & 8.0 \\
\hline Ren & renin & 8.0 \\
\hline Fpgt & fucose-1-phosphate guanylyltransferase & 8.0 \\
\hline $\operatorname{Slc} 25 \mathrm{a} 45$ & solute carrier family 25 , member 45 & 8.0 \\
\hline Olr1229 & olfactory receptor 1229 & 7.9 \\
\hline Apc2 & adenomatosis polyposis coli 2 & 7.9 \\
\hline Ing5 & inhibitor of growth family, member 5 & 7.9 \\
\hline Cnksr1 & connector enhancer of kinase suppressor of Ras 1 & 7.9 \\
\hline Gngt2 & G protein, gamma transducing activity polypeptide 2 & 7.8 \\
\hline Uggt1 & UDP-glucose glycoprotein glucosyltransferase 1 & 7.8 \\
\hline Cryab & crystallin, alpha B & 7.8 \\
\hline Ang & angiogenin, ribonuclease, RNase A family, 5 & 7.8 \\
\hline Trex2 & three prime repair exonuclease 2 & 7.8 \\
\hline Zfp295 & zinc finger protein 295 & 7.8 \\
\hline Polrmt & polymerase (RNA) mitochondrial (DNA directed) & 7.8 \\
\hline Dnal1 & dynein, axonemal, light chain 1 & 7.8 \\
\hline C1qtnf4 & $\mathrm{C} 1 \mathrm{q}$ and tumor necrosis factor related protein 4 & 7.8 \\
\hline Kif26b & kinesin family member $26 \mathrm{~B}$ & 7.7 \\
\hline Hebp 1 & heme binding protein 1 & 7.7 \\
\hline Mfn1 & mitofusin 1 & 7.7 \\
\hline Man2a2 & mannosidase 2 , alpha 2 & 7.7 \\
\hline Opn3 & opsin 3 & 7.7 \\
\hline Dsn1 & DSN1, MIND kinetochore complex component, homolog (S. cerevisiae) & 7.6 \\
\hline $\mathrm{Npl}$ & $\mathrm{N}$-acetylneuraminate pyruvate lyase & 7.6 \\
\hline Lsr & lipolysis stimulated lipoprotein receptor & 7.6 \\
\hline Syndig1 & synapse differentiation inducing 1 & 7.6 \\
\hline Nos1ap & nitric oxide synthase 1 (neuronal) adaptor protein & 7.6 \\
\hline Cbln 2 & cerebellin 2 precursor & 7.6 \\
\hline Catsper3 & cation channel, sperm associated 3 & 7.5 \\
\hline Snn & stannin & 7.5 \\
\hline Rasa2 & RAS p21 protein activator 2 & 7.5 \\
\hline Wipi2 & WD repeat domain, phosphoinositide interacting 2 & 7.5 \\
\hline $\operatorname{Arl5a}$ & ADP-ribosylation factor-like $5 \mathrm{~A}$ & 7.5 \\
\hline $\mathrm{P} 2 \mathrm{rx} 3$ & purinergic receptor $\mathrm{P} 2 \mathrm{X}$, ligand-gated ion channel, 3 & 7.5 \\
\hline Tmem132a & transmembrane protein $132 \mathrm{~A}$ & 7.5 \\
\hline Hiflan & hypoxia-inducible factor 1 , alpha subunit inhibitor & 7.4 \\
\hline Akr1c13 & aldo-keto reductase family 1 , member $\mathrm{C} 13$ & 7.4 \\
\hline Cav3 & caveolin 3 & 7.4 \\
\hline Ppp1r3b & protein phosphatase 1 , regulatory subunit $3 \mathrm{~B}$ & 7.4 \\
\hline Dync2li1 & dynein cytoplasmic 2 light intermediate chain 1 & 7.4 \\
\hline Sord & sorbitol dehydrogenase & 7.4 \\
\hline Otud3 & OTU domain containing 3 & 7.4 \\
\hline Car6 & carbonic anhydrase 6 & 7.3 \\
\hline Radil & Ras association and DIL domains & 7.3 \\
\hline Layn & layilin & 7.3 \\
\hline
\end{tabular}




\begin{tabular}{|c|c|c|}
\hline Gene Symbol & Description & Fold Change $(\log 2)$ \\
\hline Tacc3 & transforming, acidic coiled-coil containing protein 3 & 7.3 \\
\hline Grhl3 & grainyhead-like 3 (Drosophila) & 7.3 \\
\hline Elf1 & E74-like factor 1 & 7.3 \\
\hline Lrrc4c & leucine rich repeat containing $4 \mathrm{C}$ & 7.3 \\
\hline Vps4a & vacuolar protein sorting 4 homolog A (S. cerevisiae) & 7.2 \\
\hline Mast3 & microtubule associated serine/threonine kinase 3 & 7.2 \\
\hline RGD1307621 & hypothetical LOC314168 & 7.2 \\
\hline Entpd5 & ectonucleoside triphosphate diphosphohydrolase 5 & 7.2 \\
\hline Pde $3 b$ & phosphodiesterase 3B, cGMP-inhibited & 7.2 \\
\hline Myh11 & myosin, heavy chain 11 , smooth muscle & 7.1 \\
\hline Synpr & synaptoporin & 7.1 \\
\hline $\mathrm{Cdc} 20$ & cell division cycle 20 homolog (S. cerevisiae) & 7.1 \\
\hline Galnt4 & GalNAc-T4 & 7.1 \\
\hline LOC100188933 & hypothetical protein LOC100188933 & 7.1 \\
\hline Meox2 & mesenchyme homeobox 2 & 7.1 \\
\hline Krt19 & keratin 19 & 7.1 \\
\hline Ints 12 & integrator complex subunit 12 & 7.1 \\
\hline RGD1564854 & similar to divalent cation tolerant protein CUTA & 7.1 \\
\hline Tmem125 & transmembrane protein 125 & 7.1 \\
\hline Scara5 & scavenger receptor class A, member 5 (putative) & 7.0 \\
\hline Tmem81 & transmembrane protein 81 & 7.0 \\
\hline Bcar3 & breast cancer anti-estrogen resistance 3 & 7.0 \\
\hline Mypn & myopalladin & 6.9 \\
\hline Cetn4 & centrin 4 & 6.9 \\
\hline Spc25 & SPC25, NDC80 kinetochore complex component, homolog (S. cerevisiae) & 6.9 \\
\hline Atf7 & activating transcription factor 7 & 6.9 \\
\hline Slc30a9 & solute carrier family 30 (zinc transporter), member 9 & 6.9 \\
\hline $\mathrm{Zic} 4$ & Zic family member 4 & 6.9 \\
\hline Galntl1 & galactosamine:polypeptide $\mathrm{N}$-acetylgalactosaminyltransferase-like 1 & 6.9 \\
\hline Pigw & phosphatidylinositol glycan anchor biosynthesis, class W & 6.9 \\
\hline Gstm5 & glutathione S-transferase, mu 5 & 6.9 \\
\hline $\operatorname{Dd} 25$ & hypothetical protein $\mathrm{Dd} 25$ & 6.9 \\
\hline St14 & suppression of tumorigenicity 14 (colon carcinoma) & 6.9 \\
\hline RGD1305014 & similar to RIKEN cDNA $2310057 \mathrm{M} 21$ & 6.8 \\
\hline Apbb1ip & A4 precursor protein-binding, family $\mathrm{B}$, member 1 interacting protein & 6.8 \\
\hline Haus3 & HAUS augmin-like complex, subunit 3 & 6.8 \\
\hline Serpinf2 & serpin peptidase inhibitor, clade F, member 2 & 6.8 \\
\hline Psmb9 & proteasome (prosome, macropain) subunit, beta type 9 & 6.8 \\
\hline Rsph9 & radial spoke head 9 homolog (Chlamydomonas) & 6.8 \\
\hline Pvrl2 & poliovirus receptor-related 2 & 6.8 \\
\hline Slc39a8 & solute carrier family 39 (zinc transporter), member 8 & 6.8 \\
\hline Adam 4 & a disintegrin and metalloprotease domain 4 & 6.8 \\
\hline Akr1c2 & aldo-keto reductase family 1 , member $\mathrm{C} 2$ & 6.8 \\
\hline Galnt16 & galactosamine:polypeptide $\mathrm{N}$-acetylgalactosaminyltransferase-like 6 & 6.8 \\
\hline Nedd41 & neural precursor cell expressed, developmentally down-regulated 4-like & 6.7 \\
\hline Syncrip & synaptotagmin binding, cytoplasmic RNA interacting protein & 6.7 \\
\hline Hyal6 & hyaluronoglucosaminidase 6 & 6.7 \\
\hline Bend6 & BEN domain containing 6 & 6.7 \\
\hline Spag4 & sperm associated antigen 4 & 6.6 \\
\hline $\mathrm{Cx} 3 \mathrm{cll}$ & chemokine (C-X3-C motif) ligand 1 & 6.6 \\
\hline
\end{tabular}




\begin{tabular}{|c|c|c|}
\hline Gene Symbol & Description & Fold Change $(\log 2)$ \\
\hline Gnb4 & guanine nucleotide binding protein (G protein), beta polypeptide 4 & 6.6 \\
\hline Col23a1 & collagen, type XXIII, alpha 1 & 6.6 \\
\hline Atxn3 & ataxin 3 & 6.6 \\
\hline RGD1563547 & RGD1563547 & 6.6 \\
\hline Rhbdl1 & rhomboid, veinlet-like 1 (Drosophila) & 6.6 \\
\hline RGD1562726 & similar to Putative protein $\mathrm{C} 21$ orf62 homolog & 6.5 \\
\hline Shank1 & SH3 and multiple ankyrin repeat domains 1 & 6.5 \\
\hline Nln & neurolysin (metallopeptidase M3 family) & 6.5 \\
\hline Epn3 & epsin 3 & 6.5 \\
\hline Ccde64 & coiled-coil domain containing 64 & 6.5 \\
\hline Fam $186 b$ & family with sequence similarity 186 , member B & 6.5 \\
\hline Lyl1 & lymphoblastic leukemia derived sequence 1 & 6.5 \\
\hline Rc3h2 & ring finger and $\mathrm{CCCH}$-type domains 2 & 6.4 \\
\hline Nexn & nexilin ( $\mathrm{F}$ actin binding protein) & 6.4 \\
\hline Map3k1 & mitogen activated protein kinase kinase kinase 1 & 6.4 \\
\hline Akt1 & v-akt murine thymoma viral oncogene homolog 1 & 6.4 \\
\hline Tmem171 & transmembrane protein 171 & 6.4 \\
\hline Bpifb1 & BPI fold containing family $\mathrm{B}$, member 1 & 6.4 \\
\hline Tmtc4 & transmembrane and tetratricopeptide repeat containing 4 & 6.4 \\
\hline Ormd13 & ORM1-like 3 (S. cerevisiae) & 6.4 \\
\hline Olr1225 & olfactory receptor 1225 & 6.3 \\
\hline Bcmo1 & beta-carotene 15,15 '-monooxygenase 1 & 6.3 \\
\hline Spink2 & serine peptidase inhibitor, Kazal type 2 (acrosin-trypsin inhibitor) & 6.3 \\
\hline Rassf5 & Ras association (RalGDS/AF-6) domain family member 5 & 6.3 \\
\hline Map4k1 & mitogen activated protein kinase kinase kinase kinase 1 & 6.3 \\
\hline Acads & acyl-CoA dehydrogenase, $\mathrm{C}-2$ to $\mathrm{C}-3$ short chain & 6.3 \\
\hline Fcgbp & Fc fragment of $\operatorname{IgG}$ binding protein & 6.3 \\
\hline Krt8 & keratin 8 & 6.3 \\
\hline Mxd1 & max dimerization protein 1 & 6.2 \\
\hline Cdca8 & cell division cycle associated 8 & 6.2 \\
\hline Efna4 & ephrin A4 & 6.2 \\
\hline Rbmx & RNA binding motif protein, $\mathrm{X}$-linked & 6.2 \\
\hline Pcdhb9 & protocadherin beta 9 & 6.2 \\
\hline Fkbp11 & FK506 binding protein 11 & 6.2 \\
\hline B3galt4 & UDP-Gal:betaGlcNAc beta 1,3-galactosyltransferase, polypeptide 4 & 6.1 \\
\hline Ppp2r5c & protein phosphatase 2 , regulatory subunit B', gamma & 6.1 \\
\hline Lyst & lysosomal trafficking regulator & 6.1 \\
\hline Zbtb40 & zinc finger and BTB domain containing 40 & 6.1 \\
\hline $\mathrm{Pa} 2 \mathrm{~g} 4$ & proliferation-associated $2 \mathrm{G} 4$ & 6.1 \\
\hline Zbtb8a & zinc finger and BTB domain containing $8 \mathrm{a}$ & 6.1 \\
\hline Reep1 & receptor accessory protein 1 & 6.1 \\
\hline Actn1 & actinin, alpha 1 & 6.0 \\
\hline Ifih1 & interferon induced with helicase $\mathrm{C}$ domain 1 & 6.0 \\
\hline Kctd11 & potassium channel tetramerisation domain containing 11 & 6.0 \\
\hline Rin3 & Ras and Rab interactor 3 & 6.0 \\
\hline Tasp1 & taspase, threonine aspartase 1 & 6.0 \\
\hline $\operatorname{Mef} 2 \mathrm{~d}$ & myocyte enhancer factor $2 \mathrm{D}$ & 6.0 \\
\hline Gpx2 & glutathione peroxidase 2 & 6.0 \\
\hline Atp6v1e2 & ATPase, $\mathrm{H}$ transporting, lysosomal V1 subunit E2 & 6.0 \\
\hline Usp12 & ubiquitin specific peptidase 12 & 6.0 \\
\hline
\end{tabular}


Supplementary Table S2 (continued)

\begin{tabular}{|c|c|c|}
\hline Gene Symbol & Description & Fold Change $(\log 2)$ \\
\hline A1i3 & alpha-1-inhibitor III & 6.0 \\
\hline Clgn & calmegin & 6.0 \\
\hline Smtn & smoothelin & 6.0 \\
\hline Pde $7 b$ & phosphodiesterase 7B & 5.9 \\
\hline Zbtb38 & zinc finger and BTB domain containing 38 & 5.9 \\
\hline Arrdc2 & arrestin domain containing 2 & 5.9 \\
\hline Lrrc27 & leucine rich repeat containing 27 & 5.9 \\
\hline Rufy2 & RUN and FYVE domain containing 2 & 5.9 \\
\hline Traf3ip1 & TNF receptor-associated factor 3 interacting protein 1 & 5.9 \\
\hline Pex11a & peroxisomal biogenesis factor 11 alpha & 5.9 \\
\hline Smpd3 & sphingomyelin phosphodiesterase 3 , neutral membrane & 5.9 \\
\hline Espl1 & extra spindle pole bodies homolog 1 (S. cerevisiae) & 5.8 \\
\hline Rinl & Ras and Rab interactor-like & 5.8 \\
\hline Fam198b & family with sequence similarity 198 , member B & 5.8 \\
\hline Slc30a1 & solute carrier family 30 (zinc transporter), member 1 & 5.8 \\
\hline Abi3 & ABI family, member 3 & 5.8 \\
\hline Ramp2 & receptor ( $\mathrm{G}$ protein-coupled) activity modifying protein 2 & 5.8 \\
\hline Exosc2 & exosome component 2 & 5.8 \\
\hline Opn4 & opsin 4 & 5.7 \\
\hline Atf3 & activating transcription factor 3 & 5.7 \\
\hline Evc2 & Ellis van Creveld syndrome 2 homolog (human) & 5.7 \\
\hline Ang1 & angiogenin, ribonuclease A family, member 1 & 5.7 \\
\hline Mfsd7 & major facilitator superfamily domain containing 7 & 5.7 \\
\hline Lyzl6 & lysozyme-like 6 & 5.7 \\
\hline Tbxa2r & thromboxane A2 receptor & 5.7 \\
\hline Fam132a & family with sequence similarity 132 , member $\mathrm{A}$ & 5.7 \\
\hline LOC100362783 & Uncharacterized protein C7orf61 homolog & 5.7 \\
\hline Naalad11 & N-acetylated alpha-linked acidic dipeptidase-like 1 & 5.7 \\
\hline Spa17 & sperm autoantigenic protein 17 & 5.6 \\
\hline Exnef & exonuclease NEF-sp & 5.6 \\
\hline Tpk1 & thiamin pyrophosphokinase 1 & 5.6 \\
\hline LOC502684 & hypothetical protein LOC502684 & 5.6 \\
\hline Kif20b & kinesin family member 20B & 5.6 \\
\hline Clint1 & clathrin interactor 1 & 5.6 \\
\hline Iah1 & isoamyl acetate-hydrolyzing esterase 1 homolog (S. cerevisiae) & 5.6 \\
\hline Slc39a12 & solute carrier family 39 (zinc transporter), member 12 & 5.6 \\
\hline Epb49 & erythrocyte membrane protein band 4.9 (dematin) & 5.6 \\
\hline Ankrd34a & ankyrin repeat domain $34 \mathrm{~A}$ & 5.6 \\
\hline Aoc3 & amine oxidase, copper containing 3 (vascular adhesion protein 1 ) & 5.5 \\
\hline Ppp1r1a & protein phosphatase 1 , regulatory (inhibitor) subunit $1 \mathrm{~A}$ & 5.5 \\
\hline Polb & polymerase (DNA directed), beta & 5.5 \\
\hline Supt71 & suppressor of Ty 7 (S. cerevisiae)-like & 5.5 \\
\hline $\operatorname{Tg}$ & thyroglobulin & 5.5 \\
\hline $\mathrm{Cd} 46$ & CD46 molecule, complement regulatory protein & 5.5 \\
\hline Cntrob & centrobin, centrosomal BRCA2 interacting protein & 5.5 \\
\hline Mepe & matrix extracellular phosphoglycoprotein & 5.5 \\
\hline Lgals3bp & lectin, galactoside-binding, soluble, 3 binding protein & 5.5 \\
\hline Smtnl2 & smoothelin-like 2 & 5.4 \\
\hline Omd & osteomodulin & 5.4 \\
\hline Pdhx & pyruvate dehydrogenase complex, component $\mathrm{X}$ & 5.4 \\
\hline
\end{tabular}


Supplementary Table S2 (continued)

\begin{tabular}{|c|c|c|}
\hline Gene Symbol & Description & Fold Change (log2) \\
\hline $\mathrm{R} \ln 1$ & relaxin 1 & 5.4 \\
\hline Rnf144a & ring finger protein $144 \mathrm{~A}$ & 5.4 \\
\hline Nod1 & nucleotide-binding oligomerization domain containing 1 & 5.4 \\
\hline Heph & hephaestin & 5.4 \\
\hline Usp31 & ubiquitin specific peptidase 31 & 5.4 \\
\hline Dcps & decapping enzyme, scavenger & 5.4 \\
\hline Stk35 & serine/threonine kinase 35 & 5.3 \\
\hline Gbas & glioblastoma amplified sequence & 5.3 \\
\hline Folr1 & folate receptor 1 (adult) & 5.3 \\
\hline Arfip1 & ADP-ribosylation factor interacting protein 1 & 5.3 \\
\hline Slc16a1 & solute carrier family 16 , member 1 & 5.3 \\
\hline RGD1560909 & similar to DNA segment, Chr 1, Brigham \& Womens Genetics 0212 expressed & 5.3 \\
\hline Lect1 & leukocyte cell derived chemotaxin 1 & 5.3 \\
\hline Sbk1 & SH3-binding domain kinase 1 & 5.3 \\
\hline LOC100360582 & 5',3'-nucleotidase, cytosolic & 5.3 \\
\hline Ambp & alpha-1-microglobulin/bikunin precursor & 5.3 \\
\hline Srpx & sushi-repeat-containing protein, $\mathrm{X}$-linked & 5.3 \\
\hline Tmem144 & transmembrane protein 144 & 5.3 \\
\hline Zbtb3 & zinc finger and BTB domain containing 3 & 5.3 \\
\hline Erp27 & endoplasmic reticulum protein 27 & 5.3 \\
\hline Tgm 1 & transglutaminase $1, \mathrm{~K}$ polypeptide & 5.2 \\
\hline Cdkn2aip & CDKN2A interacting protein & 5.2 \\
\hline Megf9 & multiple EGF-like-domains 9 & 5.2 \\
\hline Gdf10 & growth differentiation factor 10 & 5.2 \\
\hline Rasal2 & RAS protein activator like 2 & 5.2 \\
\hline Nme4 & non-metastatic cells 4 , protein expressed in & 5.2 \\
\hline Fam83h & family with sequence similarity 83 , member $\mathrm{H}$ & 5.2 \\
\hline Ccdc86 & coiled-coil domain containing 86 & 5.2 \\
\hline Pr18a5 & prolactin family 8 , subfamily a, member 5 & 5.2 \\
\hline Arnt & aryl hydrocarbon receptor nuclear translocator & 5.2 \\
\hline Slc24a3 & solute carrier family 24 , member 3 & 5.1 \\
\hline Bhlhe22 & basic helix-loop-helix family, member e22 & 5.1 \\
\hline Trim72 & tripartite motif-containing 72 & 5.1 \\
\hline Ube2f & ubiquitin-conjugating enzyme E2F (putative) & 5.1 \\
\hline Tmem151a & transmembrane protein $151 \mathrm{~A}$ & 5.1 \\
\hline Slc1a3 & solute carrier family 1 , member 3 & 5.1 \\
\hline Tff3 & trefoil factor 3 , intestinal & 5.1 \\
\hline Mgrn1 & mahogunin, ring finger 1 & 5.1 \\
\hline Slc7a5 & solute carrier family 7 , member 5 & 5.1 \\
\hline Spata2 & spermatogenesis associated 2 & 5.0 \\
\hline Atg10 & autophagy-related 10 (S. cerevisiae) & 5.0 \\
\hline Pdzk1 & PDZ domain containing 1 & 5.0 \\
\hline Rxra & retinoid $\mathrm{X}$ receptor alpha & 5.0 \\
\hline Zfp94 & zinc finger protein 94 & 5.0 \\
\hline Tmem209 & transmembrane protein 209 & 5.0 \\
\hline Spopl & speckle-type POZ protein-like & 5.0 \\
\hline B4galt1 & UDP-Gal:betaGlcNAc beta 1,4- galactosyltransferase, polypeptide 1 & 5.0 \\
\hline $\mathrm{Hmmr}$ & hyaluronan mediated motility receptor (RHAMM) & 5.0 \\
\hline Slc7a3 & solute carrier family 7 , member 3 & 4.9 \\
\hline Tpx2 & TPX2, microtubule-associated, homolog (Xenopus laevis) & 4.9 \\
\hline
\end{tabular}




\begin{tabular}{|c|c|c|}
\hline Gene Symbol & Description & Fold Change $(\log 2)$ \\
\hline Serpinb8 & serpin peptidase inhibitor, clade B (ovalbumin), member 8 & 4.9 \\
\hline Cpne5 & copine V & 4.9 \\
\hline Dnajc5 & DnaJ (Hsp40) homolog, subfamily C, member 5 & 4.9 \\
\hline RGD1564482 & RGD1564482 & 4.9 \\
\hline Chrne & cholinergic receptor, nicotinic, epsilon & 4.9 \\
\hline Tifa & TRAF-interacting protein with forkhead-associated domain & 4.9 \\
\hline Arhgap29 & Rho GTPase activating protein 29 & 4.9 \\
\hline Fert2 & fer $(\mathrm{fms} / \mathrm{fps}$ related) protein kinase, testis specific 2 & 4.9 \\
\hline Max & MYC associated factor $\mathrm{X}$ & 4.8 \\
\hline Fam122a & family with sequence similarity $122 \mathrm{~A}$ & 4.8 \\
\hline Cenpf & centromere protein $\mathrm{F}$ & 4.8 \\
\hline Etv4 & ets variant 4 & 4.8 \\
\hline Atp8b1 & ATPase, Class I, type 8B, member 1 & 4.8 \\
\hline Cenl2 & cyclin L2 & 4.8 \\
\hline Raly & RNA binding protein, autoantigenic & 4.8 \\
\hline Dnajb4 & DnaJ (Hsp40) homolog, subfamily B, member 4 & 4.8 \\
\hline Recq14 & RecQ protein-like 4 & 4.8 \\
\hline Magt1 & magnesium transporter 1 & 4.8 \\
\hline Nnat & neuronatin & 4.8 \\
\hline Nkd1 & naked cuticle homolog 1 (Drosophila) & 4.8 \\
\hline Irak4 & interleukin-1 receptor-associated kinase 4 & 4.8 \\
\hline Scn1a & sodium channel, voltage-gated, type I, alpha & 4.8 \\
\hline Ptch1 & patched 1 & 4.7 \\
\hline Casc5 & cancer susceptibility candidate 5 & 4.7 \\
\hline Adamts 1 & ADAM metallopeptidase with thrombospondin type 1 motif, 1 & 4.7 \\
\hline Kbtbd11 & kelch repeat and BTB (POZ) domain containing 11 & 4.7 \\
\hline RGD1311863 & similar to RIKEN cDNA $2410127 \mathrm{~L} 17$ & 4.7 \\
\hline Ribc1 & RIB43A domain with coiled-coils 1 & 4.7 \\
\hline Ghdc & GH3 domain containing & 4.7 \\
\hline Hspa12a & heat shock protein $12 \mathrm{~A}$ & 4.7 \\
\hline Hsdl2 & hydroxysteroid dehydrogenase like 2 & 4.7 \\
\hline Rcbtb2 & $\mathrm{RCC} 1$ and $\mathrm{BTB}$ domain containing protein 2 & 4.7 \\
\hline Trmt11 & tRNA methyltransferase 11 homolog (S. cerevisiae) & 4.6 \\
\hline Myo10 & myosin $\mathrm{X}$ & 4.6 \\
\hline Ankrd6 & ankyrin repeat domain 6 & 4.6 \\
\hline $\mathrm{T} 2$ & brachyury 2 & 4.6 \\
\hline Zbtb10 & zinc finger and BTB domain containing 10 & 4.6 \\
\hline Ftsjd1 & FtsJ methyltransferase domain containing 1 & 4.6 \\
\hline Lgals4 & lectin, galactoside-binding, soluble, 4 & 4.6 \\
\hline Galnt7 & GalNAc-T7 & 4.6 \\
\hline Slc25a37 & solute carrier family 25 , member 37 & 4.6 \\
\hline Sstr1 & somatostatin receptor 1 & 4.6 \\
\hline Gpm6b & glycoprotein m6b & 4.6 \\
\hline Dep1a & DCP1 decapping enzyme homolog A (S. cerevisiae) & 4.6 \\
\hline Asz1 & ankyrin repeat, SAM and basic leucine zipper domain containing 1 & 4.6 \\
\hline Tmem86a & transmembrane protein $86 \mathrm{~A}$ & 4.6 \\
\hline Ugtla6 & UDP glucuronosyltransferase 1 family, polypeptide A6 & 4.5 \\
\hline Prss36 & protease, serine, 36 & 4.5 \\
\hline Tial1 & Tial cytotoxic granule-associated RNA binding protein-like 1 & 4.5 \\
\hline Defb27 & defensin beta 27 & 4.5 \\
\hline
\end{tabular}




\begin{tabular}{|c|c|c|}
\hline Gene Symbol & Description & Fold Change $(\log 2)$ \\
\hline Tbkbp 1 & TBK1 binding protein 1 & 4.4 \\
\hline Fam176a & family with sequence similarity 176 , member A & 4.4 \\
\hline Mylk3 & myosin light chain kinase 3 & 4.4 \\
\hline C1qtnf1 & $\mathrm{C} 1 \mathrm{q}$ and tumor necrosis factor related protein 1 & 4.4 \\
\hline Sbno2 & strawberry notch homolog 2 (Drosophila) & 4.4 \\
\hline Fsip1 & fibrous sheath interacting protein 1 & 4.4 \\
\hline Chaflb & chromatin assembly factor 1 , subunit B (p60) & 4.4 \\
\hline MGC95152 & similar to B230212L03Rik protein & 4.4 \\
\hline Wdr72 & WD repeat domain 72 & 4.4 \\
\hline Polq & polymerase (DNA directed), theta & 4.3 \\
\hline Ugt1a9 & UDP glucuronosyltransferase 1 family, polypeptide A9 & 4.3 \\
\hline Mtf2 & metal response element binding transcription factor 2 & 4.3 \\
\hline Wwox & WW domain-containing oxidoreductase & 4.3 \\
\hline Ugt1a8 & UDP glycosyltransferase 1 family, polypeptide A 8 & 4.3 \\
\hline Ugtla7c & UDP glucuronosyltransferase 1 family, polypeptide A7C & 4.3 \\
\hline Ugt1a5 & UDP glucuronosyltransferase 1 family, polypeptide A5 & 4.3 \\
\hline Ugt1a3 & UDP glycosyltransferase 1 family, polypeptide A3 & 4.3 \\
\hline Ugt1a2 & UDP glucuronosyltransferase 1 family, polypeptide A2 & 4.3 \\
\hline Ugt1a1 & UDP glucuronosyltransferase 1 family, polypeptide A1 & 4.3 \\
\hline Sgms2 & sphingomyelin synthase 2 & 4.3 \\
\hline Prkar2b & protein kinase, cAMP dependent regulatory, type II beta & 4.3 \\
\hline Decr2 & 2,4-dienoyl CoA reductase 2, peroxisomal & 4.3 \\
\hline Fam83d & family with sequence similarity 83 , member D & 4.3 \\
\hline Sult1a1 & sulfotransferase family, cytosolic, $1 \mathrm{~A}$, phenol-preferring, member 1 & 4.3 \\
\hline Kifc1 & kinesin family member $\mathrm{C} 1$ & 4.2 \\
\hline Opa1 & optic atrophy 1 homolog (human) & 4.2 \\
\hline Rab11fip2 & RAB11 family interacting protein 2 (class I) & 4.2 \\
\hline Gtse1 & G-2 and S-phase expressed 1 & 4.2 \\
\hline Slc27a6 & solute carrier family 27 (fatty acid transporter), member 6 & 4.2 \\
\hline Cep55 & centrosomal protein 55 & 4.2 \\
\hline Agmo & alkylglycerol monooxygenase & 4.2 \\
\hline $\operatorname{Slc} 25 \mathrm{a} 30$ & solute carrier family 25 , member 30 & 4.2 \\
\hline $\operatorname{Len} 2$ & lipocalin 2 & 4.2 \\
\hline Nalcn & sodium leak channel, non-selective & 4.2 \\
\hline Robo2 & roundabout homolog 2 (Drosophila) & 4.2 \\
\hline Asrg11 & asparaginase like 1 & 4.2 \\
\hline Lepr & leptin receptor & 4.2 \\
\hline Mbtps2 & membrane-bound transcription factor peptidase, site 2 & 4.1 \\
\hline Pllp & plasmolipin & 4.1 \\
\hline $\operatorname{Slc} 22 \mathrm{a} 20$ & solute carrier family 22 (organic anion transporter), member 20 & 4.1 \\
\hline Ext13 & exostoses (multiple)-like 3 & 4.1 \\
\hline Pygo1 & pygopus 1 & 4.1 \\
\hline Lefty 1 & left right determination factor 1 & 4.1 \\
\hline Map4k2 & mitogen activated protein kinase kinase kinase kinase 2 & 4.1 \\
\hline $\operatorname{rnf141}$ & ring finger protein 141 & 4.1 \\
\hline Ocrl & oculocerebrorenal syndrome of Lowe & 4.1 \\
\hline Mfap5 & microfibrillar associated protein 5 & 4.1 \\
\hline Crk & v-crk sarcoma virus CT10 oncogene homolog (avian) & 4.1 \\
\hline Cmtm8 & CKLF-like MARVEL transmembrane domain containing 8 & 4.0 \\
\hline $\operatorname{Ddx} 25$ & DEAD (Asp-Glu-Ala-Asp) box polypeptide 25 & 4.0 \\
\hline
\end{tabular}




\begin{tabular}{|c|c|c|}
\hline Gene Symbol & Description & Fold Change $(\log 2)$ \\
\hline Kenh2 & potassium voltage-gated channel, subfamily $\mathrm{H}$ (eag-related), member 2 & 4.0 \\
\hline Fndc $3 b$ & fibronectin type III domain containing $3 \mathrm{~B}$ & 4.0 \\
\hline Fxr1 & fragile $\mathrm{X}$ mental retardation, autosomal homolog 1 & 4.0 \\
\hline Dkk1 & dickkopf homolog 1 (Xenopus laevis) & 4.0 \\
\hline Nphp3 & nephronophthisis 3 (adolescent) & 4.0 \\
\hline Srsf10 & serine/arginine-rich splicing factor 10 & 4.0 \\
\hline Ttbk2 & tau tubulin kinase 2 & 4.0 \\
\hline Homez & homeobox and leucine zipper encoding & 4.0 \\
\hline Stard5 & StAR-related lipid transfer (START) domain containing 5 & 4.0 \\
\hline Cxadr & coxsackie virus and adenovirus receptor & 4.0 \\
\hline Ano4 & anoctamin 4 & 4.0 \\
\hline Slc6a2 & solute carrier family 6 , member 2 & 4.0 \\
\hline Ube2cbp & ubiquitin-conjugating enzyme $\mathrm{E} 2 \mathrm{C}$ binding protein & 4.0 \\
\hline Mitf & microphthalmia-associated transcription factor & 3.9 \\
\hline Erc1 & ELKS/RAB6-interacting/CAST family member 1 & 3.9 \\
\hline Pik3cd & phosphoinositide-3-kinase, catalytic, delta polypeptide & 3.9 \\
\hline Tbc1d7 & TBC1 domain family, member 7 & 3.9 \\
\hline Akr1e2 & aldo-keto reductase family 1 , member E2 & 3.9 \\
\hline Rab3d & RAB3D, member RAS oncogene family & 3.9 \\
\hline Cenpm & centromere protein $\mathrm{M}$ & 3.9 \\
\hline Chchd5 & coiled-coil-helix-coiled-coil-helix domain containing 5 & 3.9 \\
\hline Prrx2 & paired related homeobox 2 & 3.8 \\
\hline Slmo1 & slowmo homolog 1 (Drosophila) & 3.8 \\
\hline $\mathrm{Em} 12$ & echinoderm microtubule associated protein like 2 & 3.8 \\
\hline Sh3bp1 & SH3-domain binding protein 1 & 3.8 \\
\hline Btrc & beta-transducin repeat containing & 3.8 \\
\hline Phlpp1 & PH domain and leucine rich repeat protein phosphatase 1 & 3.8 \\
\hline Rpp38 & ribonuclease P/MRP 38 subunit (human) & 3.8 \\
\hline Tnks & tankyrase, TRF1-interacting ankyrin-related ADP-ribose polymerase & 3.8 \\
\hline Reep6 & receptor accessory protein 6 & 3.8 \\
\hline Fblim 1 & filamin binding LIM protein 1 & 3.8 \\
\hline Fam25a & family with sequence similarity 25 , member $\mathrm{A}$ & 3.7 \\
\hline Sema4g & Semaphorin $4 \mathrm{G}$ & 3.7 \\
\hline Ppplr3a & protein phosphatase 1 , regulatory subunit $3 \mathrm{~A}$ & 3.7 \\
\hline Traf3ip3 & TRAF3 interacting protein 3 & 3.7 \\
\hline Rnf17 & ring finger protein 17 & 3.7 \\
\hline Steap1 & six transmembrane epithelial antigen of the prostate 1 & 3.7 \\
\hline Ikbip & IKBKB interacting protein & 3.7 \\
\hline Mpp2 & membrane protein, palmitoylated 2 (MAGUK p55 subfamily member 2) & 3.7 \\
\hline Pde12 & phosphodiesterase 12 & 3.7 \\
\hline Lxn & latexin & 3.7 \\
\hline Alox12 & arachidonate 12-lipoxygenase & 3.7 \\
\hline $\mathrm{Nt} 5 \mathrm{c} 3$ & 5'-nucleotidase, cytosolic III & 3.6 \\
\hline Gnb5 & guanine nucleotide binding protein (G protein), beta 5 & 3.6 \\
\hline Jph3 & junctophilin 3 & 3.6 \\
\hline Ttc $7 \mathrm{~b}$ & tetratricopeptide repeat domain $7 \mathrm{~B}$ & 3.6 \\
\hline D2hgdh & D-2-hydroxyglutarate dehydrogenase & 3.6 \\
\hline Cdkn2c & cyclin-dependent kinase inhibitor $2 \mathrm{C}$ (p18, inhibits CDK4) & 3.6 \\
\hline Cachd1 & cache domain containing 1 & 3.6 \\
\hline Kbtbd5 & kelch repeat and BTB (POZ) domain containing 5 & 3.6 \\
\hline
\end{tabular}


Supplementary Table S2 (continued)

\begin{tabular}{|c|c|c|}
\hline Gene Symbol & Description & Fold Change $(\log 2)$ \\
\hline Pex7 & peroxisomal biogenesis factor 7 & 3.6 \\
\hline Tomm34 & translocase of outer mitochondrial membrane 34 & 3.6 \\
\hline Arse & arylsulfatase E (chondrodysplasia punctata 1) & 3.6 \\
\hline Fubp1 & far upstream element (FUSE) binding protein 1 & 3.6 \\
\hline RGD1563159 & RGD1563159 & 3.6 \\
\hline Npw & neuropeptide $\mathrm{W}$ & 3.6 \\
\hline Mia & melanoma inhibitory activity & 3.6 \\
\hline Mcee & methylmalonyl CoA epimerase & 3.5 \\
\hline RGD1563325 & similar to hypothetical protein MGC17943 & 3.5 \\
\hline Slc26a4 & solute carrier family 26 , member 4 & 3.5 \\
\hline Fbxo28 & F-box protein 28 & 3.5 \\
\hline Ccdc102a & coiled-coil domain containing $102 \mathrm{~A}$ & 3.5 \\
\hline Rtn4ip1 & reticulon 4 interacting protein 1 & 3.5 \\
\hline Lrrc4 & leucine rich repeat containing 4 & 3.5 \\
\hline RGD1305537 & similar to RIKEN cDNA $3110001 \mathrm{I} 22$ & 3.5 \\
\hline Tprg1 & tumor protein p63 regulated 1 & 3.5 \\
\hline Kenn2 & potassium intermediate/small conductance calcium-activated channel, N2 & 3.5 \\
\hline Rgl3 & ral guanine nucleotide dissociation stimulator-like 3 & 3.5 \\
\hline $\operatorname{Sim} 2$ & single-minded homolog 2 (Drosophila) & 3.5 \\
\hline Usp46 & ubiquitin specific peptidase 46 & 3.5 \\
\hline Ehd3 & EH-domain containing 3 & 3.5 \\
\hline Cubn & cubilin (intrinsic factor-cobalamin receptor) & 3.4 \\
\hline Cers 1 & ceramide synthase 1 & 3.4 \\
\hline Gdf1 & growth differentiation factor 1 & 3.4 \\
\hline Piwil2 & piwi-like 2 (Drosophila) & 3.4 \\
\hline Rabif & $\mathrm{RAB}$ interacting factor & 3.4 \\
\hline Hyal3 & hyaluronoglucosaminidase 3 & 3.4 \\
\hline Rab30 & RAB30, member RAS oncogene family & 3.4 \\
\hline Syt11 & synaptotagmin-like 1 & 3.4 \\
\hline Gpc2 & glypican 2 & 3.4 \\
\hline Zmat4 & zinc finger, matrin type 4 & 3.3 \\
\hline $\operatorname{Ttc} 25$ & tetratricopeptide repeat domain 25 & 3.3 \\
\hline Il22 & interleukin 22 & 3.3 \\
\hline Mid1ip1 & MID1 interacting protein 1 (gastrulation specific G12 homolog (zebrafish)) & 3.3 \\
\hline Mutyh & mutY homolog (E. coli) & 3.3 \\
\hline Flnc & filamin $\mathrm{C}$, gamma & 3.3 \\
\hline Tshz3 & teashirt zinc finger homeobox 3 & 3.3 \\
\hline Pdxp & pyridoxal (pyridoxine, vitamin B6) phosphatase & 3.3 \\
\hline Acsl3 & acyl-CoA synthetase long-chain family member 3 & 3.3 \\
\hline Lpin1 & lipin 1 & 3.2 \\
\hline Zc3hav1 & zinc finger $\mathrm{CCCH}$ type, antiviral 1 & 3.2 \\
\hline Bfsp1 & beaded filament structural protein 1 & 3.2 \\
\hline Fermt3 & fermitin family member 3 & 3.2 \\
\hline Trim13 & tripartite motif-containing 13 & 3.2 \\
\hline Magix & MAGI family member, X-linked & 3.2 \\
\hline Cyp2d4 & cytochrome P450, family 2 , subfamily d, polypeptide 4 & 3.2 \\
\hline Abcb7 & ATP-binding cassette, subfamily B (MDR/TAP), member 7 & 3.2 \\
\hline Pigy & phosphatidylinositol glycan anchor biosynthesis, class $\mathrm{Y}$ & 3.2 \\
\hline Ppm1h & protein phosphatase $1 \mathrm{H}$ (PP2C domain containing) & 3.2 \\
\hline $\operatorname{Tm} 7 \mathrm{sf} 2$ & transmembrane 7 superfamily member 2 & 3.2 \\
\hline
\end{tabular}




\begin{tabular}{|c|c|c|}
\hline Gene Symbol & Description & Fold Change $(\log 2)$ \\
\hline Wnt3 & wingless-type MMTV integration site family, member 3 & 3.2 \\
\hline $\mathrm{Cp}$ & ceruloplasmin & 3.2 \\
\hline St5 & suppression of tumorigenicity 5 & 3.2 \\
\hline Мyo5a & myosin VA & 3.1 \\
\hline Ptpla & protein tyrosine phosphatase-like (proline instead of catalytic arginine), member a & 3.1 \\
\hline Smo & smoothened, frizzled family receptor & 3.1 \\
\hline Nog & noggin & 3.1 \\
\hline Mmp3 & matrix metallopeptidase 3 & 3.1 \\
\hline Trim37 & tripartite motif-containing 37 & 3.1 \\
\hline Lactb2 & lactamase, beta 2 & 3.1 \\
\hline Slc5a12 & solute carrier family 5 (sodium/glucose cotransporter), member 12 & 3.0 \\
\hline RGD1310553 & similar to expressed sequence AI597479 & 3.0 \\
\hline Tmem $38 b$ & transmembrane protein $38 \mathrm{~B}$ & 3.0 \\
\hline Trim14 & tripartite motif-containing 14 & 2.9 \\
\hline Spatal & spermatogenesis associated 1 & 2.9 \\
\hline RGD1561149 & similar to mKIAA1522 protein & 2.9 \\
\hline Tmem79 & transmembrane protein 79 & 2.9 \\
\hline Ctnnd1 & catenin (cadherin associated protein), delta 1 & 2.9 \\
\hline Dnaja4 & DnaJ (Hsp40) homolog, subfamily A, member 4 & 2.9 \\
\hline Rhbdd2 & rhomboid domain containing 2 & 2.9 \\
\hline Nudt21 & nudix (nucleoside diphosphate linked moiety X)-type motif 21 & 2.9 \\
\hline Pdk3 & pyruvate dehydrogenase kinase, isozyme 3 & 2.9 \\
\hline Arhgap4 & Rho GTPase activating protein 4 & 2.9 \\
\hline Stk381 & serine/threonine kinase 38 like & 2.9 \\
\hline Hsf4 & heat shock transcription factor 4 & 2.9 \\
\hline Mark4 & MAP/microtubule affinity-regulating kinase 4 & 2.9 \\
\hline Fto & fat mass and obesity associated & 2.8 \\
\hline Vps72 & vacuolar protein sorting 72 homolog (S. cerevisiae) & 2.8 \\
\hline Pcsk6 & proprotein convertase subtilisin/kexin type 6 & 2.8 \\
\hline Ube216 & ubiquitin-conjugating enzyme E2L 6 & 2.8 \\
\hline LOC361346 & similar to chromosome 18 open reading frame 54 & 2.8 \\
\hline Mterfd 1 & MTERF domain containing 1 & 2.8 \\
\hline Gpn2 & GPN-loop GTPase 2 & 2.8 \\
\hline LOC100362431 & tetratricopeptide repeat domain $30 \mathrm{~B}$ & 2.8 \\
\hline Arsg & arylsulfatase G & 2.8 \\
\hline RGD1308428 & similar to RIKEN cDNA $4931406 \mathrm{P} 16$ & 2.8 \\
\hline Zfp655 & zinc finger protein 655 & 2.7 \\
\hline Trhr & thyrotropin releasing hormone receptor & 2.7 \\
\hline Ccde61 & coiled-coil domain containing 61 & 2.7 \\
\hline Azi1 & 5-azacytidine induced 1 & 2.7 \\
\hline Dnmt3b & DNA (cytosine-5-)-methyltransferase 3 beta & 2.7 \\
\hline RGD1563941 & similar to hypothetical protein FLJ20010 & 2.7 \\
\hline Nradd & neurotrophin receptor associated death domain & 2.7 \\
\hline Mapk1ip11 & mitogen-activated protein kinase 1 interacting protein 1 -like & 2.7 \\
\hline Col9a2 & collagen, type IX, alpha 2 & 2.7 \\
\hline Col9a1 & collagen, type IX, alpha 1 & 2.7 \\
\hline Spin1 & spindlin 1 & 2.7 \\
\hline Cib2 & calcium and integrin binding family member 2 & 2.7 \\
\hline C1qtnf3 & $\mathrm{Clq}$ and tumor necrosis factor related protein 3 & 2.6 \\
\hline Epyc & epiphycan & 2.6 \\
\hline
\end{tabular}


Supplementary Table S2 (continued)

\begin{tabular}{|c|c|c|}
\hline Gene Symbol & Description & Fold Change $(\log 2)$ \\
\hline Tmem169 & transmembrane protein 169 & 2.6 \\
\hline Stradb & STE20-related kinase adaptor beta & 2.6 \\
\hline Fkbp7 & FK506 binding protein 7 & 2.6 \\
\hline Rps6ka1 & ribosomal protein S6 kinase polypeptide 1 & 2.6 \\
\hline Tctex $1 \mathrm{~d} 2$ & Tctex 1 domain containing 2 & 2.6 \\
\hline Plekhh3 & pleckstrin homology domain containing, family H (with MyTH4 domain) member 3 & 2.6 \\
\hline Gins4 & GINS complex subunit 4 (Sld5 homolog) & 2.6 \\
\hline Wdr19 & WD repeat domain 19 & 2.6 \\
\hline Trub1 & TruB pseudouridine (psi) synthase homolog 1 (E. coli) & 2.6 \\
\hline Fahd1 & fumarylacetoacetate hydrolase domain containing 1 & 2.6 \\
\hline Slc34a3 & solute carrier family 34 (sodium phosphate), member 3 & 2.6 \\
\hline Edem 3 & ER degradation enhancer, mannosidase alpha-like 3 & 2.6 \\
\hline Slc12a3 & solute carrier family 12 (sodium/chloride transporters), member 3 & 2.5 \\
\hline Cblc & Cas-Br-M (murine) ecotropic retroviral transforming sequence $\mathrm{c}$ & 2.5 \\
\hline LOC499643 & similar to hypothetical protein FLJ25371 & 2.5 \\
\hline Mug2 & murinoglobulin 2 & 2.5 \\
\hline Isg20 & interferon stimulated exonuclease gene 20 & 2.5 \\
\hline Lum & lumican & 2.5 \\
\hline Zpbp2 & zona pellucida binding protein 2 & 2.5 \\
\hline Cpne8 & copine VIII & 2.5 \\
\hline Pir & pirin (iron-binding nuclear protein) & 2.5 \\
\hline Zfp7 & zinc finger protein 7 & 2.4 \\
\hline Pcsk1n & proprotein convertase subtilisin/kexin type 1 inhibitor & 2.4 \\
\hline Sec23ip & SEC23 interacting protein & 2.4 \\
\hline Rab4b & RAB4B, member RAS oncogene family & 2.4 \\
\hline Tomm 40 & translocase of outer mitochondrial membrane 40 homolog (yeast) & 2.4 \\
\hline Tapbp & TAP binding protein & 2.4 \\
\hline Pi15 & peptidase inhibitor 15 & 2.4 \\
\hline Hacl1 & 2-hydroxyacyl-CoA lyase 1 & 2.4 \\
\hline Usp15 & ubiquitin specific peptidase 15 & 2.4 \\
\hline G3bp2 & GTPase activating protein ( $\mathrm{SH} 3$ domain) binding protein 2 & 2.3 \\
\hline Zdhhc2 & zinc finger, DHHC-type containing 2 & 2.3 \\
\hline Rhobtb3 & Rho-related BTB domain containing 3 & 2.3 \\
\hline Fgd1 & FYVE, RhoGEF and PH domain containing 1 & 2.3 \\
\hline Gpx7 & glutathione peroxidase 7 & 2.3 \\
\hline RGD1305939 & hypothetical LOC300074 & 2.3 \\
\hline Egfl7 & EGF-like-domain, multiple 7 & 2.2 \\
\hline Slc3a1 & solute carrier family 3 , member 1 & 2.2 \\
\hline Man1a2 & mannosidase, alpha, class $1 \mathrm{~A}$, member 2 & 2.2 \\
\hline Klhl36 & kelch-like 36 (Drosophila) & 2.2 \\
\hline Prrc1 & proline-rich coiled-coil 1 & 2.2 \\
\hline Cep97 & centrosomal protein 97 & 2.2 \\
\hline Anks1a & ankyrin repeat and sterile alpha motif domain containing $1 \mathrm{~A}$ & 2.2 \\
\hline Fam35a & family with sequence similarity 35 , member A & 2.2 \\
\hline Ece2 & endothelin-converting enzyme 2 & 2.1 \\
\hline Slc8a3 & solute carrier family 8 (sodium/calcium exchanger), member 3 & 2.1 \\
\hline Fbln5 & fibulin 5 & 2.1 \\
\hline LOC690918 & hypothetical protein LOC690918 & 2.0 \\
\hline
\end{tabular}

